Brit. F. industr. Med., 1968, 25, 81 .

\title{
Some Electrophysiological Methods for Studying the Action of Narcotic Agents in Animals, with special reference to Industrial Solvents : A Review
}

\author{
HANA MIKISKOVÁ and ALOŠ MIKISKA \\ From the Institute of Industrial Hygiene and Occupational Diseases, Prague, Czechoslovakia
}

Four electrophysiological methods, two based on stimulation (measurement of spinal reflex excitability and of direct excitability of the cerebral motor cortex) and two based on bioelectric recording (electroencephalography and electrocardiography), were used in intact guinea-pigs and rabbits for studying the action of narcotic and anaesthetic agents, especially of industrial solvents. The authors' results have been reviewed and compared with those of other investigators in an attempt to work out experimental procedures for routine toxicity testing.

The object of this paper is the description and analysis of several electrophysiological methods with respect to their application for testing the toxicity of industrial poisons in animals. Only those techniques are described in detail that have proved reliable for evaluating narcotic agents, especially solvents. Other techniques that can be directly compared with ours are also discussed. We also present some new toxicity data which illustrate the contribution of electrophysiological methods to the solution of toxicological problems.

The investigation of the functional state of tissues and organs, as well as of their morphological and biochemical states, is important, especially for the central nervous system. Even very slight and transitory functional nervous disturbances may have serious consequences in affected workers, by increasing accidents and errors in performance.

Many nervous functions, particularly the most complicated ones, can only be studied in humans. Nevertheless, animal experiments are indispensable in this field, because in animals it is possible to test higher concentrations of poisons, and the action of substances recently introduced into industry, as well as to study the mechanisms of action in more detail.

A useful addition to neurophysiological methods is the electrocardiogram. It provides data on the central nervous control of autonomic functions and allows the study of pharmacodynamic or toxic

Received for publication September 4, 1967 . effects on an excitable tissue whose cyclic excitability changes can be estimated more simply than those of the central nervous system.

For assessing the hazard of a chemical substance a quantitative comparison of its toxic effect in relation to the effects of chemically related substances may be of special importance: the determination of relative toxicity is usually more accurate and reliable than a direct estimation of a minimum effective dose or concentration. Our effort was therefore directed towards choosing or working out electrophysiological methods which permit an exact quantitative evaluation of the toxic effect. In addition, we aimed to standardize measurement procedures to facilitate a comparison of results obtained in various laboratories.

In its classical form, electrophysiology was divided into two large sections, dealing with problems (I) of tissue conductivity and excitability and (2) of bioelectrical potentials and currents. There are no strict boundaries between them today, but in practice excitability measurements still differ greatly from biopotential recording and analysis. When excitability is measured for toxicity testing one must take into account that the physiological processes evoked by the stimulation can influence the course of the poisoning (phenomena of 'electronarcosis', etc.), whereas when spontaneous bioelectrical activity is examined, the fixation of the animal and the application of the electrodes are the only factors that can affect the findings. Leading off biopotentials and recording them have no relevant effect. Consequently, biopotential recording has 
become the basis of routine clinical examination techniques; and toxicological data in animals from electroencephalogram (E.E.G.), electrocardiogram (E.C.G.), and electromyogram (E.M.G.) recordings can often be compared with clinical findings in affected humans.

Our experiments were performed in rabbits and guinea-pigs, because these species were found to be most suitable for evaluating narcotic industrial poisons by electrophysiological techniques. The rabbit's size permits this animal to be used simultaneously for biochemical studies. Guinea-pigs, on the other hand, may be handled more easily and, as a rule, they are more quiet during recording. In guinea-pigs, all the methods discussed have been tested in control experiments as well as with some typical narcotic agents in order to compare their reliability, validity, and sensitivity.

Statistical significance throughout was calculated as described by Mann and Whitney (1947). This non-parametric ranking test makes no assumptions either about the type of distribution of the population from which samples are taken or about the constancy of variance in two groups, one treated, the other not. Treatment may change both distribution and variance. Statistical significance has been, therefore, under- rather than over-estimated in all instances.

\section{Measurement of Spinal Reflex Excitability}

Segmental spinal monosynaptic and polysynaptic reflexes are simple functions of the central nervous system which can be easily evaluated by quantitative techniques and which are therefore suitable for pharmacological and toxicological research of central nervous depressants. As for other types of excitability measurement, the functional state of the nervous centre can be inferred either from the latency and size of the reflex response evoked by the stimulus of a constant predetermined intensity, or from the threshold stimulus intensity, e.g., the threshold voltage or current of an electrical stimulus whose other parameters, such as duration and repetition rate, are kept constant. The latter technique, applied to a defensive reflex reaction following electrical stimulation of cutaneous receptors of guinea-pig hind limbs, proved to be a useful test for screening the neurotoxicity of industrial solvents and other narcotic agents.

Procedure Two copper discs (about $4 \mathrm{~cm}$. diameter), covered with several layers of flannel soaked in $5 \%$ aqueous sodium chloride, serve as the stimulating electrodes. The distance between the centres of the electrodes is adjusted according to the animal's size, being on an average about $8 \mathrm{~cm}$. During measurement, the guinea-pig is held by the experimenter so that it touches the electrodes with its hind paws, previously wetted by dipping into $5 \%$ saline. A stimulator with constant current output (e.g., Multistim-DISA, Herlev, Denmark, used in our laboratory) is necessary in order that the stimulating current should not be dependent on the resistance of the skin and electrodes. The stimulation is effected by rectangular impulses of $3 \mathrm{msec}$. duration, repeated with the frequency of $0.8 \mathrm{c} / \mathrm{s}$. The current is increased from zero in steps of about $0.2 \mathrm{~mA}$, stimulation by each current being repeated three or four times. A current that evokes a motor response to each stimulus is taken as the threshold. The response to a threshold stimulus is the dorsal flexion of the toes in rhythm with the stimulation. When the stimulus is increased further, flexion in all three joints of the hind limbs results. In untreated guinea-pigs, the threshold current varies from about 0.4 to $1.6 \mathrm{~mA}$, and is distributed approximately normally. Experiments have shown that the threshold current cannot be considered as an individual characteristic of each animal, stable for a long time. It should not be measured more often than once a day, in order to prevent formation of a conditioned reflex, which is, as a rule, associated with a decrease in threshold. Therefore, the following design of experiment is recommended. The threshold current should be measured simultaneously in several randomly selected groups, each consisting of at least ro animals. The control group is injected with physiological saline (or the solvent for the test compound) or exposed to a stream of pure air in inhalation experiments. The significance level of the results can be evaluated according to statistical tests for samples of independent observations (Student's twosample $t$-test, Mann-Whitney's U-test, regression analysis, etc.).

Results Some of the results, i.e., those concerning the action of ethanol, trichloroethylene, trichloroethanol, and chloral hydrate, are summarized in Table I. All were administered to guinea-pigs by intraperitoneal injection. Their depressant effects were tested at their peaks20 to 30 minutes after trichloroethylene and ro to I5 minutes after the other compounds.

An increase in the threshold current, approximately in direct proportion to the dose, was observed for all these compounds. The linear dependence was valid only within certain dose limits; larger doses caused complete abolition of spinal reflex excitability. The following equations were the best estimates of the straight line regression of threshold current $(\mathrm{Y}$, in $\mathrm{mA}) v$. dose $(\mathrm{X}$, in $\mathrm{mM} . / \mathrm{kg}$.):

$$
\begin{aligned}
& \mathbf{Y}=0.02 \mathbf{I X}+0.975 \text { for ethanol } \\
& \mathbf{Y}=0.104 X+0.985 \text { for trichloroethylene } \\
& \mathbf{Y}=0.539 \mathrm{X}+\mathbf{I} \cdot 184 \text { for trichloroethanol } \\
& \mathbf{Y}=0.6 \mathrm{IIX}+\mathbf{I} \cdot 090 \text { for chloral hydrate. }
\end{aligned}
$$


TABLE I

Action of Some Central Nervous Depressants (administered intraperitoneally) on the Threshold CuRrent INTENSITY OF SKIN STIMULATION OF THE HiNd LimbS IN GUINEA-PIGS

\begin{tabular}{|c|c|c|c|c|c|c|c|c|c|}
\hline \multicolumn{5}{|c|}{ Compound } & \multirow{2}{*}{$\begin{array}{c}\begin{array}{c}\text { Dose } \\
\text { (mM./kg.) }\end{array} \\
0 \\
6 \cdot 7 \\
13 \cdot 4\end{array}$} & \multirow{2}{*}{$\begin{array}{c}\text { No. of } \\
\text { Animals } \\
\text { I9 } \\
\text { 19 } \\
\text { I9 }\end{array}$} & \multirow{2}{*}{$\begin{array}{c}\text { Threshold Current } \\
\begin{array}{c}(M e a n \pm S . E . M .) \\
(m A)\end{array} \\
0.974 \pm 0.041 \\
\text { I.124 } \pm 0.100 \\
\text { I.253 } 0.074\end{array}$} & \multirow{2}{*}{$\begin{array}{l}\begin{array}{c}\text { Difference from } \\
\text { Control Group } \\
(\%)\end{array} \\
+15.4 \\
+28.7\end{array}$} & \multirow{2}{*}{$\begin{array}{c}\text { Significance } \\
\text { N.S. } \\
0.005\end{array}$} \\
\hline Ethanol & . & $\cdots$ & $\cdots$ & $\cdots$ & & & & & \\
\hline Trichloroethylene & & $\cdots$ & . & $\cdots$ & $\begin{array}{l}0 \\
3 \cdot 34 \\
6 \cdot 7\end{array}$ & $\begin{array}{r}25 \\
15 \\
8\end{array}$ & $\begin{array}{l}0.980 \pm 0.047 \\
I .360 \pm 0.082 \\
I .575 \pm 0.215\end{array}$ & $\begin{array}{r}+38.8 \\
+60.7\end{array}$ & $\begin{array}{l}0.001 \\
0.001\end{array}$ \\
\hline Trichloroethanol & . & $\cdots$ & $\cdots$ & . & $\begin{array}{l}0 \\
0.84 \\
1.67\end{array}$ & $\begin{array}{l}17 \\
17 \\
17\end{array}$ & $\begin{array}{l}\mathbf{I} \cdot \mathbf{1 8 8} \pm 0.059 \\
\mathbf{I} \cdot 618 \pm 0.087 \\
\mathbf{2} \cdot 106 \pm 0.119\end{array}$ & $\begin{array}{l}+36 \cdot 1 \\
+77 \cdot 2\end{array}$ & $\begin{array}{l}0.001 \\
0.001\end{array}$ \\
\hline Chloral hydrate & $\cdots$ & $\cdots$ & . & . & $\begin{array}{l}0 \\
0.84 \\
I \cdot 67\end{array}$ & $\begin{array}{l}20 \\
20 \\
20\end{array}$ & $\begin{array}{l}1.085 \pm 0.048 \\
1.660 \pm 0.115 \\
2.075 \pm 0.137\end{array}$ & $\begin{array}{l}+53.0 \\
+91.3\end{array}$ & $\begin{array}{l}0.001 \\
0.001\end{array}$ \\
\hline
\end{tabular}

The slopes are a measure of relative neurotoxicity with respect to spinal reflex excitability.

Regression lines for trichloroethylene and trichloroethanol have been presented elsewhere (Mikisková and Mikiska, I966). In the present paper, Fig. 3 shows a comparison of trichloroethylene, chloral hydrate, and dial. The large black circles (upper right) indicate approximately equally effective doses, each compound at those doses evoking a threshold increase of about $60 \%$.

As the three compounds represent different groups of anaesthetics and, therefore, cannot be compared on the basis of molar doses, we decided to use the equi-effective doses $(6.7 \mathrm{mM}$. $/ \mathrm{kg}$. of trichloroethylene, $0.84 \mathrm{mM}$. $/ \mathrm{kg}$. of chloral hydrate, and $0.19 \mathrm{mM}$. $/ \mathrm{kg}$. of dial) in further trials with other electrophysiological techniques.

Discussion Experiments testing the action of drugs on spinal reflex excitability have been designed either to study the mechanisms of the pharmacodynamic action, especially to reveal the mechanisms of muscular relaxation in anaesthesia, or for the quantitative estimation of toxicity. Mechanisms have mostly been studied in surgically prepared animals, e.g., spinal, decerebrated or decapitated preparations with exposed nerve trunks or spinal roots for electrical stimulation or recording. For toxicity testing, animals with an intact nervous system are more suitable.

A review dealing with both types of problems from the pioneer work of Sherrington (1906, 1909) up to the present has been given by Mikisková
(1962). (An extended version in English can be obtained from the author on request.) In this paper we shall limit the discussion to work related to the methods used in our laboratory.

Rozin (1954), working with rats and mice, was probably the first to eliminate fixation of the animal in spinal reflex studies. $\mathrm{He}$ held the animals by hand during stimulation. The voltage was chosen in advance and the number of impulses $(2 / \mathrm{sec}$.) required to evoke the flexion of one limb was counted before and after exposure to toxic substances. This technique, extensively used in Russian laboratories of industrial toxicology, is referred to as 'testing the summation ability of the central nervous system'. For example, Oljunin (1957, 1958) has published results concerning threshold toxic concentrations of acetone, diethyl ether, benzene and xylene, while Korbakova, Kremneva, Kulagina, and Ulanova (1960) have used this technique to study rats with chronic benzene poisoning.

Bartenev (I96I) stood the animal on two metal bars, fixed in a special stand and wrapped with wet gauze, that served as stimulating electrodes. The first movement of any extremity due to stimulation was regarded as a positive reaction. Speranskij (I962) used the same electrode arrangement but used a gradually increasing voltage. $\mathrm{He}$ was, therefore, testing rather the threshold voltage than the summation ability.

The variant introduced since $196 \mathrm{I}$ in the toxicological laboratory of Korbakova (personal communication) represents, in our experience, a definite 
improvement. It consists of (I) the use of a stimulator with constant current output, and (2) a slower frequency of impulse $(0.8 \mathrm{c} / \mathrm{s}$, and impulse duration $3 \mathrm{msec}$.). We recommend these conditions for routine testing. For rats they give closely similar threshold currents to those found in guinea-pigs (Mikisková and Mikiska, I962, and this paper).

All these responses differ physiologically from the classical flexion reflex, as defined by Sherrington (I906), and first studied in poisoned animals with intact nervous systems by Zakusov (1948, 1953). During simultaneous stimulation of both hind paws, opposite reactions would come from the afferent nerves in each limb (ipsilateral flexion $v$. crossed extensor reflex), if the integrative action of the spinal cord did not inhibit one of the reactions. If all four limbs are stimulated at once, the situation is still more complicated, because the current flowing through each paw depends on the skin resistance and cannot be controlled by the experimental design. For this reason techniques based on simultaneous use of more than two stimulation electrodes cannot be recommended.

There is much terminological confusion in toxicological literature. The determination of spinal reflex excitability in intact animals used for testing industrial poisons is often referred to as 'determination of neuromuscular excitability', which suggests that the response to direct stimulation of muscle or its motor nerve is being studied. It seems, therefore, necessary to submit evidence that for general anaesthetics, and probably for other narcotic compounds too, the action manifesting itself in the test results is mediated through the synapses of the central nervous system, and that the functional changes in the common efferent path can be neglected.

Depression or complete abolition of motor responses elicited by electrical stimulation of skin receptors in the animal with an intact nervous system gives an over-all indication of the pharmacodynamic effect which may be caused in many ways. The cause may involve functional deterioration of any of the following systems: receptors, afferent nerve fibres, spinal reflex centres, the motor area of the cerebral cortex with its tracts, brain-stem activating systems, common efferent motor paths, neuromuscular transmission of excitation, and the contractility of the muscles.

Excitability of receptors during anaesthesia has been studied by most authors for lung receptors only. The observation by Matthews (1933) that the excitability of muscle spindles is increased during ether anaesthesia is difficult to compare with other data. The concentrations of narcotic compounds which affect impulse transmission in peripheral nerves in vitro are usually several times greater than those blocking synaptic transmission (Larrabee and Posternak, I952; Toman, 1952).

The possibility that depression of neuromuscular transmission may play a part in muscular relaxation and reflex abolition during surgical anaesthesia has been investigated by many authors (Naess, I950a, b, c; Secher, I950, I95Ia, b, c, d; Sabawala and Dillon, 1958). It has been found, however, only for ether, and that only in the tolerance stage, while for the other anaesthetics tested (cyclopropane, chloroform, halothane, barbiturates, and other drugs) concentrations blocking neuromuscular transmission in vitro were higher than any concentration in blood or tissues found in general anaesthesia. This also holds for inhibition of muscle contractility.

It appears, therefore, that deterioration of central nervous synaptic transmission is the principal factor in the depression of spinal reflexes. Occasionally a drug is effective in a decapitated animal at a concentration equal to that causing only moderate anaesthesia in the intact animal (ethanol in the cat (Kolmodin, I953)); but the depression of brain-stem activating systems appears to be controlling in intact animals (Magoun and Rhines, 1946; Niemer and Magoun, 1947).

The depression of synaptic transmission is greatly dependent on the number, and repetition rate, of afferent impulses as well as on specific features of the compound. A review on this subject, starting from the pioneer observations of Bremer and Bonnet (1948), was given by Schneider (I954).

Conclusions The measurement of the threshold current for the skin stimulation of hind limbs is a simple way of estimating quantitatively spinal reflex excitability in intact animals. Its use does not need any special instruments and the measurements can be performed quickly on large groups of animals. For screening tests as well as for estimating relative toxicities these features enable one to obtain statistically significant results. On the other hand, the examination cannot be repeated within a short time interval, so that the time course of action cannot be studied. It is also impossible to study differences between animals in their sensitivity to drugs; and experimental results cannot be compared directly with clinical observations and experiments.

We should like, however, to stress that these disadvantages are common to all tests of spinal reflex excitability, including those more elaborate and time-consuming (Zakusov, I948, I953; Ljublina, I948, 1959). 


\section{Measurement of Electrical Excitability of the Cerebral Motor Cortex}

The excitability of nervous centres can be estimated not only with reflex stimulation via receptors or afferent nerve fibres, but also by direct electrical stimulation of the central nervous system tissue. The motor area of the cerebral cortex seems to be one of the most suitable structures for the use of direct electrical stimulation in applied research, because it may be easily exposed both for acute experiments and for implantation of electrodes, and because its stimulation results in constant, clearly defined motor responses. For drug evaluation, there are the following principal possibilities:

(I) estimation of the response intensity to stimulation of the motor area by electrical current of constant parameters (Wyke, 1955);

(2) estimation of the response latency with constant stimulation parameters (Zakusov, 1953; Baryšnikov, Vinogradov, Nikiforov, and Šanin, 1956); and

(3) determination of the threshold voltage and/or current of the electrical stimulation. This is preferred by most other authors. Reproducible results can, however, be obtained only with repeated stimulation (Mikiska, 1960).

Method For acute studies basal anaesthesia can hardly be avoided (Bohm and Petersén, 1953). For pharmacological and toxicological experiments the use of implanted electrodes is necessary for testing the threshold before administration of the drug. The following procedure of implantation is used in our laboratory (Králová, Mikiska and Pařizek, I957; Mikiska, I960).

The electrode consists of two contacts of silver wire, embedded in an electrode body made of polymethylmethacrylate (as used in dentistry). The form and size of the electrodes for rabbits and guinea-pigs are shown in Figure I.

Implantation is performed under dial anaesthesia (40 mg. $/ \mathrm{kg} .=0.19 \mathrm{mM} . / \mathrm{kg}$. intraperitoneally). Twenty to 30 minutes after dial injection the skin is infiltrated with $\mathrm{r} \%$ procaine and the surgical procedure is started. The trephining is begun on the fronto-parietal suture, about $4 \mathrm{~mm}$. from the midline in rabbits and $3 \mathrm{~mm}$. in guinea-pigs. When a small opening has been made to the dura mater, the exact localization of the motor area for the fore-limb is checked by electrical stimulation, and the opening is broadened to an elliptical shape. The cranio-cerebral topographic relations of the motor area are remarkably constant and are similar for all laboratory rodents (in Fig. I they are illustrated for the guinea-pig's skull). For electrode fixation in rabbits, the diploe is removed around the periphery of the opening to allow the electrode holders to penetrate between the lamina externa and the lamina interna of the skull bones. In guinea-pigs, the electrode holders, located on the lower edge, are inserted between the bones and the dura mater. The inserted electrode is turned to a right angle and fixed in the correct position to the bones by polymethylmethacrylate.

After the electrical excitability has been re-tested with the electrode in situ, the skin is sutured. No special post-operative care is necessary, and the reliability of the surgical procedure is nearly 100\%. Stimulation
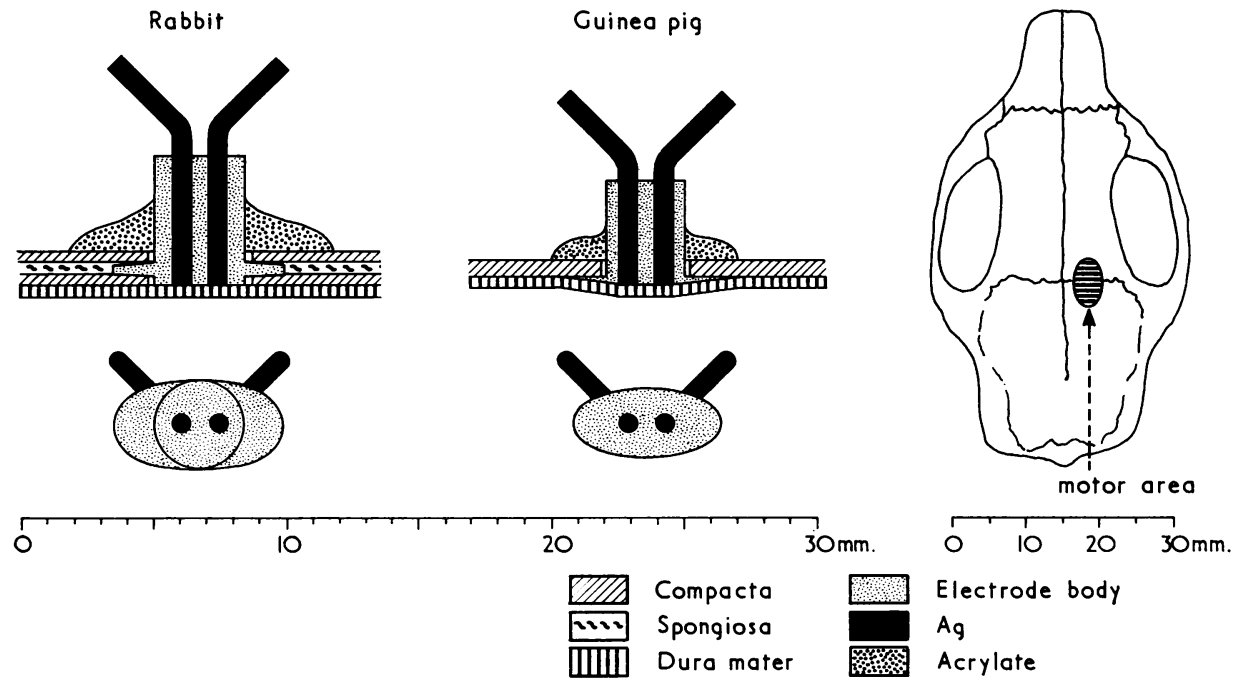

Fig. I. Bipolar epidural electrodes for electrical stimulation and E.E.G. recording. To the right the position of the motor area in the guinea-pig is shown. 
experiments can be started 5 to 8 days after implantation and continued for several weeks.

For stimulation the animal is tied to a fixation table in the ventral position by tapes attached to the extremities as for routine polygraphic recording. Stimulation of the motor area is provided by sinewave alternating current, $50 \mathrm{c} / \mathrm{s}$, transformed from the mains and switched on every sixth second for $0.6 \mathrm{sec}$. by means of an electromechanical switch. We start the stimulation with a voltage $20-30 \%$ above the expected threshold, known approximately from the earlier measurement. The voltage is then decreased in steps of about $5 \%$, stimulation being repeated three or four times at each voltage. The threshold is taken as that value which results in a stable flexion of the contralateral forelimb, not disappearing with repeated stimulation. The threshold is determined every 5 minutes; and the mean value of six estimates in half an hour is taken.

In untreated guinea-pigs and rabbits the threshold voltage found was usually I to 2 volts, R.M.S., and the fluctuation of threshold within 4 to 6 hours was very small (Mikiska, 1960). Changes were distributed approximately normally and did not exceed $\pm 6 \%$ (99\% confidence limits).
Results Intraperitoneal saline did not affect the threshold (Table II), so every significant change in the threshold following the administration of a compound is likely to be due to its pharmacological action. Reports in the literature and our own experience support the validity of a general rule that an increase in threshold voltage, reflecting a decrease in excitability, is a manifestation of a central nervous depressant effect, whereas a decrease is often a manifestation of an excitant or sub-convulsive action.

The results obtained with some narcotic agents and solvents, administered intraperitoneally to guinea-pigs, are summarized in Table II. In the homologous series of aromatic hydrocarbons the depressant action was observed to increase from benzene to xylene. On the other hand, in some experiments with benzene, a convulsive effect could be demonstrated. This was rarely observed with toluene and xylene and then only at least 90 minutes after injection. The increase in depressant action was clear even though the hydrocarbons were

TABLE II

Action of Some Organic Solvents (administered intraperitoneally) on the Threshold Stimulus Voltage (SINE-Wave $50 \mathrm{C} / \mathrm{s}$ For 0.6 SEC.) OF the Motor ARea OF the Cerebral Cortex IN Guinea-Pigs

\begin{tabular}{|c|c|c|c|c|c|}
\hline Compound & Dose & $\begin{array}{l}\text { No. of } \\
\text { Animals }\end{array}$ & $\begin{array}{l}\text { Time from } \\
\text { Injection } \\
\quad(\text { min. })\end{array}$ & $\begin{array}{c}\text { Percent Change } \\
\pm \text { S.E.M. } \\
\text { of Threshold }\end{array}$ & Significance \\
\hline $0.9 \%$ sol. $\mathrm{NaCl}$ & $0.4 \mathrm{ml}$ & 6 & $\begin{array}{r}5-30 \\
65-90 \\
155-180\end{array}$ & $\begin{array}{lll}- & 1 \cdot 7 \pm & 1 \cdot 0 \\
- & 1 \cdot 3 \pm & 0 \cdot 8 \\
- & 1 \cdot 4 \pm & 1 \cdot 2\end{array}$ & \\
\hline Benzene & $\begin{array}{l}6.7 \mathrm{mM} . / \mathrm{kg} . \\
(0.52 \mathrm{~g} . / \mathrm{kg} .)\end{array}$ & 6 & $\begin{array}{r}5-30 \\
65-90 \\
155-180\end{array}$ & $\begin{array}{l}+\quad 1 \cdot 8 \pm 1 \cdot 7 \\
+\quad 2 \cdot 1 \pm 2 \cdot 4 \\
-\quad 3 \cdot 0 \pm 5.3\end{array}$ & \\
\hline Toluene & $\begin{array}{l}5.6 \mathrm{mM} . / \mathrm{kg} . \\
(0.52 \mathrm{~g} . / \mathrm{kg} .)\end{array}$ & 6 & $\begin{array}{r}5-30 \\
65-90 \\
155-180\end{array}$ & $\begin{array}{l}+\quad 6.0 \pm 2.6 \\
+\quad 1.6 \pm 2.0 \\
-\quad 2.7 \pm 2.8\end{array}$ & 0.013 \\
\hline \multirow{2}{*}{ Xylene } & $\begin{array}{l}3.3 \mathrm{mM} . / \mathrm{kg} . \\
(0.35 \mathrm{~g} . / \mathrm{kg} .)\end{array}$ & 6 & $\begin{array}{r}5-30 \\
65-90\end{array}$ & $\begin{array}{l}+\quad 8.0 \pm 7.7 \\
-\quad 2.2 \pm 2.5\end{array}$ & \\
\hline & $\begin{array}{l}4.9 \mathrm{mM} . / \mathrm{kg} . \\
(0.52 \mathrm{~g} . / \mathrm{kg} .)\end{array}$ & 6 & $\begin{array}{r}5-30 \\
65-90\end{array}$ & $\begin{array}{r}+17.4 \pm 3.4 \\
+\quad 5.1 \pm 5.3\end{array}$ & 0.001 \\
\hline \multirow{2}{*}{ Trichloroethylene } & $\begin{array}{l}2.2 \mathrm{mM} . / \mathrm{kg} . \\
(0.29 \mathrm{~g} . / \mathrm{kg} .)\end{array}$ & 6 & $\begin{array}{r}5-30 \\
65-90 \\
155-180\end{array}$ & $\begin{array}{ll}+\quad 1.4 \pm 2.3 \\
+\quad 1.7 \pm 1.7 \\
-\quad 0.6 \pm 1.3\end{array}$ & \\
\hline & $\begin{array}{l}6.7 \mathrm{mM} / \mathrm{kg} . \\
(0.88 \mathrm{~g} . / \mathrm{kg} .)\end{array}$ & 6 & $\begin{array}{r}5-30 \\
65-90 \\
155-180\end{array}$ & $\begin{array}{l}+13.2 \pm 3.3 \\
+\quad 12.5 \pm 4.1 \\
+\quad 15.9 \pm 5.2\end{array}$ & $\begin{array}{l}0.001 \\
0.032 \\
0.008\end{array}$ \\
\hline Trichloroethanol & $\begin{array}{l}2.2 \mathrm{mM} . / \mathrm{kg} . \\
(0.34 \mathrm{~g} . / \mathrm{kg} .)\end{array}$ & 6 & $\begin{array}{r}5-30 \\
65-90 \\
155-180\end{array}$ & $\begin{array}{r}+210.7 \pm 57.3 \\
+108.0 \pm 52.2 \\
-\quad 24.5 \pm 11.6\end{array}$ & $\begin{array}{l}0.001 \\
0.001\end{array}$ \\
\hline
\end{tabular}


given in equal weight doses, i.e., in molar doses inversely proportional to the molecular weight. The analysis of these results (Mikisková, 1960) will be reviewed in the next Section.

Trichloroethylene and trichloroethanol affected the excitability of the cerebral motor cortex like typical depressants, i.e., by increasing the threshold. The relative effectiveness of both compounds, and conclusions concerning the possible role of trichloroethanol in poisoning by trichloroethylene, have been analysed by us in detail in previous work (Mikisková and Mikiska, 1960, 1963, 1966).

Discussion Direct electrical excitation of central nervous tissues has more complex consequences than has excitation of peripheral tissues -nerves or muscles. The stimulus excites thousands of neurons, mutually connected by excitatory and inhibitory synapses, which often form closed reverberating circuits. Consequently, a single stimulus causes a series of neuronal discharges lasting several seconds even in the neuronally isolated neocortex (Burns, 1951, 1954). For the intact motor cortex this repetitive discharge can easily be followed by recording from the pyramidal tracts (Brookhart and Zanchetti, 1956; Schlag, 1956).

To use a threshold for testing the action of chemical compounds, it is necessary to standardize both the stimulus and conditions which could exert reflex influences on the excitability of the cerebral motor cortex.

For the stimulus, voltage and current, waveform, duration and repetition rate of impulses, the use of unipolar or bipolar stimulation and the electrode size and shape are probably the most important things to standardize. Among reflex influences, that of proprioreceptors in muscles participating in the test response seems to be the most important, but other factors have been studied, too, such as stimulation of acoustical and tactile receptors, interoreceptors, brain-stem and diencephalic excitatory and inhibitory ascending systems, and the establishment of conditioned reflexes. Summation effects, appearing with repeated stimulation, can sometimes result in convulsive epileptoid phenomena if the stimulation is too strong or too longlasting. On the other hand, if stimulation is started at sub-threshold voltages or currents, and the stimulus is gradually increased, the appearance of a clearly defined threshold can be inhibited by adaptative processes.

We have reviewed elsewhere the data on these essential factors in a paper which describes our attempt to work out a standardized procedure for toxicological studies (Mikiska, I960).
Various centrally acting drugs and poisons can be classified into three broad groups: (I) depressants (narcotics, anaesthetics), (2) stimulants (analeptics, convulsants), and (3) compounds with more complicated mechanisms of action. The three groups will be discussed separately.

(I) Depressants uniformly evoke an increase in the threshold, which increases with the depth and duration of anaesthesia (Richard (1939) for Evipan; Rascanu, Kapri, and Popovici (1939) for chloroform, Evipan, and Veronal (barbitone); Benešová, Horváth, and Mikiska (1956) for various intravenous barbiturates; and Králová et al. (1957) for trichloroethylene). The electrophysiological effect paralleled the depression of reflex excitability, so determination of threshold voltage was taken to be a valid quantitative indicator of depth of anaesthesia, and was used for studying the synergism between barbiturates and phenothiazine derivatives (Votava, Benešová, and Metyšová, 1958) and for comparing the depressant action of trichloroethylene and trichloroethanol (Mikisková and Mikiska, I960).

Wyke (1955), who measured the excitability of a motor area from the strength of muscular contraction evoked by stimuli of constant intensity, also found a close parallelism between the decrease in cortical excitability and other measures of the depth of barbiturate anaesthesia.

Some early workers (Fulton, Liddell, and Riosh, 1930; Fulton and Keller, 1932) claimed that the excitability of the cortex is affected 'not only by the depth of anaesthesia but also by the type of anaesthetic used'. They did not, however, measure the depth of anaesthesia quantitatively and did not know the threshold of the motor area before the anaesthetic was administered. Their observations cannot therefore be compared with those of more recent authors.

Bohm and Petersén (1953) examined the increase in threshold for various parts of the motor area in dial anaesthesia. A larger effect was observed in hind limbs than in fore limbs. The same was also found in acute experiments with the use of basal anaesthesia.

(2) The increase in excitability threshold after depressants may be as high as a few hundred per cent. The maximum decrease in threshold due to analeptics and convulsants is not more than 15 to $20 \%$. Stimulation of the motor area after higher doses of excitant compounds results in motor restlessness or transient convulsions. Data on the following compounds have been published: pentamethylene tetrazole (Malkiman, 1954b); strychnine, caffeine, and amphetamine (Lev, 1956); and parathion (Králová et al., 1957). 
(3) Schlag (1956) observed an increase in the motor area excitability after several drugs, evoking vasodilatation of brain vessels: acetylcholine, eserine, methacholine, histamine, nicotinic acid, and amyl nitrite. Both increases and decreases of excitability were observed after bulbocapnine (Levitina, I948; Palatnik, 1949) and adenosintriphosphoric and monobromoacetic acid (Babskij and Malkiman, 1952; Malkiman, 1954a).

The central nervous action of aromatic hydrocarbons (Results above) consisted of both depression of cortical excitability, especially for toluene and xylene, and of an excitation, most pronounced for benzene. Other authors have also observed both effects. Lazarev (1954) reported results on rats and guinea-pigs exposed to high concentrations of aromatic hydrocarbon vapours; Ljublina (1950) evaluated the excitability for simple spinal reflex functions; in the study by Jaroslavskaja (1952) complex unconditioned reflexes were also examined; and Novikov (1956) studied conditioned reflexes.

Furnas and Hine (1958) examined the effect of aromatic hydrocarbon vapours on the E.E.G. of rats with implanted cortical electrodes. Besides narcotic effects, like those from volatile anaesthetics and lipid solvents, a spike-like E.E.G. activity was found, which was assumed to be a manifestation of a convulsant effect.

Dési and Nikolits (1967) have recently shown in cats marked facilitation, by intraperitoneal benzene and xylene, of the spike activity evoked by local application of strychnine to the neocortex, benzene being the more effective.

Conclusions Measurement of the electrical excitability of the cerebral motor cortex is a method for the quantitative estimation of the direct electrical excitability of the central nervous tissue. No special instruments are necessary to ascertain the response to stimulation. Highly reproducible, quantitative results are obtained in acute experiments lasting several hours, and individual evaluation of each experiment is possible. Excitant and depressant actions on the central nervous system result in contrary changes of the threshold voltage, so that some broad analysis of the mechanism of action is possible.

However, implantation of electrodes several days before the experiment makes the technique timeconsuming. Experimental results cannot be directly compared with clinical observations and experiments.

The methods seem to be suitable for the advanced testing of compounds, the basic toxicities of which are already known from screening or pilot experiments.

\section{Registration and Analysis of the Electroencephalogram}

Less is known about the action of industrial solvents on the E.E.G. in animal experiments than about the action of depressant pharmacological agents. There are many E.E.G. reports on humans poisoned with industrial solvents, but few for the same subjects before the poisoning. For trichloroethylene, however, carefully controlled experiments have been carried out in humans, because of its use for general anaesthesia (Schneider, 1954; Courtin, 1955; Okuma, Shimazono, and Narabayashi, 1957; Martin, Faulconer, and Bickford, 1959; Faulconer and Bickford, 196r).

For other solvents animal experiments may complement the clinical findings in patients by yielding quantitative toxicity data and by contributing to the knowledge of the mechanism of action. References will be discussed together with our experimental results.

Method Our experiments were carried out mostly on guinea-pigs or rabbits with chronically implanted epidural electrodes, localized over the motor area, i.e., with the same type as for the electrical stimulation of the motor cortex (Fig. I). Rabbits were either placed in a restraining box or tied to a table. Guinea-pigs were tied to a special fixation table. To avoid serious discomfort the head was not fixed. The animal's movements were monitored continuously by E.M.G. recording, which enabled us to discriminate slow E.E.G. waves from movement artefacts. For gross movements E.M.G. superimposed over the E.C.G. leads or special leads from both hind limbs were satisfactory, while even very small movements of the head could be clearly detected from the lead between both animal's ears.

The E.E.G. was recorded bipolarly in the unearthed animal. The amplified E.E.G. voltage was led off from one control grid of the fourth amplifier stage (output for oscilloscope, etc.) to an electronic E.E.G. integrator, and to the modulator of a frequency-modulation magnetic tape recording system. Both were of our own design (Mikiska, 1962, 1963, 1964).

The integrator, an analog device for on-line analysis (Mikiska, 1963), operated in a manner similar to the integrators designed by Drohocki (1948, 1956) and by Bickford (1950), but zero resetting was performed with an electromagnetic relay, as in the circuit used in the equipment for servo-anaesthesia by Bureš, Petráň, and Zachar (1960). The results of integration were written out on another channel of the E.E.G. as a series of impulses whose average frequency was directly proportional to the mean E.E.G. amplitude (Fig. 2). The mean E.E.G. amplitude was then determined by counting the number of integrator impulses for a representative trac- 


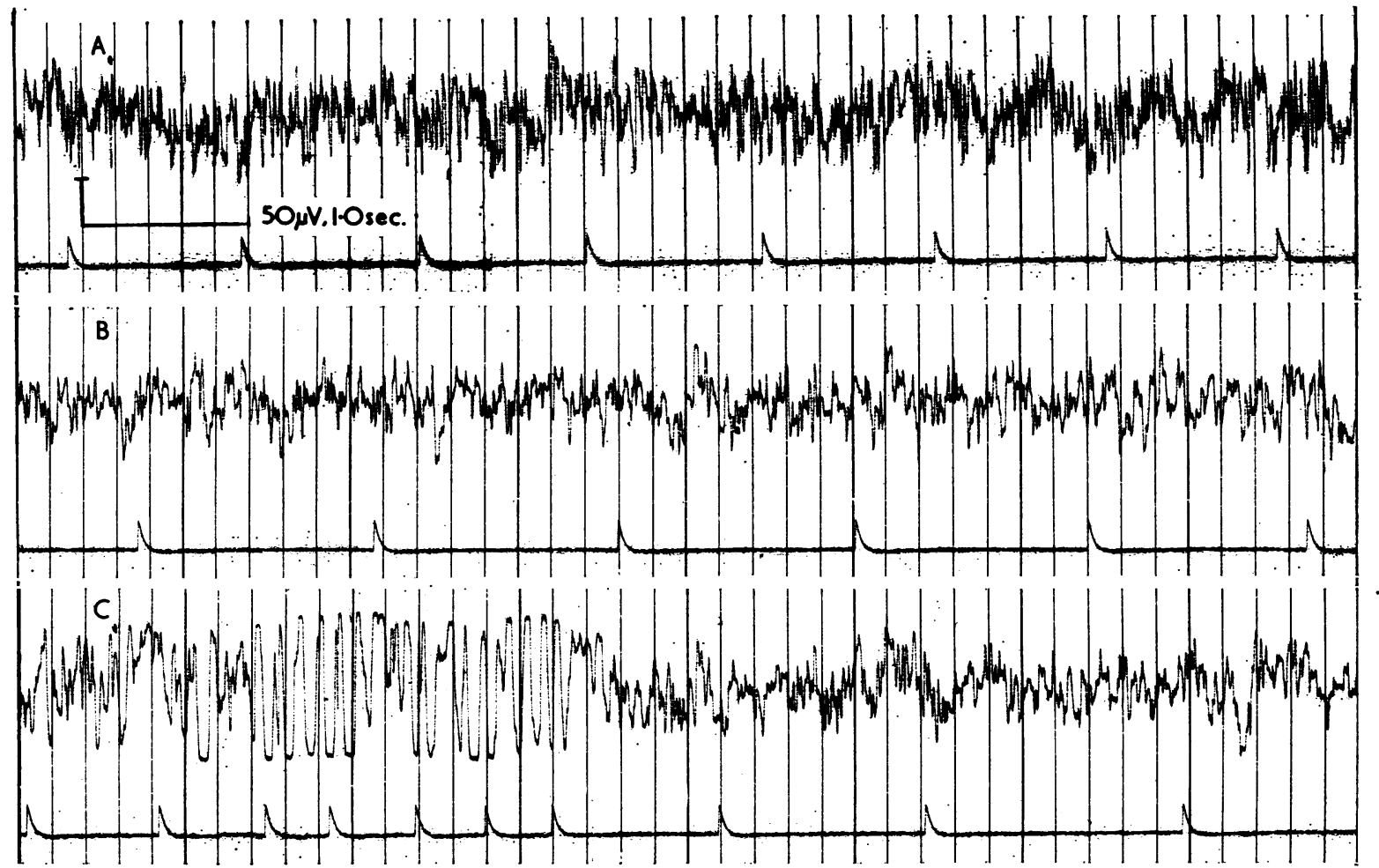

FIG. 2. Example of E.E.G. recording and integration in the guinea-pig. Integrator impulses are recorded below each E.E.G. tracing. (A) control record; (B and C) record ro min. after exposure to carbon disulphide vapours (750 p.p.m., duration 3 hrs.).

ing section over several minutes. The absence of movement artefacts in the record could be verified from the E.M.G. tracing recorded simultaneously.

The equipment for magnetic tape recording consisted of a conventional tape recorder for home use (half-track record, speed of tape $9.5 \mathrm{~cm}$. $/ \mathrm{sec}$.), a modulator, i.e., generator of an F.M.-carrier frequency $5,000 \mathrm{c} / \mathrm{s} \pm 40 \%$, and of an F.M.-demodulator. Diagrams and further technical data have been published elsewhere (Mikiska, 1962). Magnetic tape recording enabled us to analyse our E.E.G.s in another laboratory equipped with the Petersén analyser, manufactured by Kaiser Ltd. (Copenhagen) and modified by Matoušek (1967). This instrument divided the E.E.G. signal into six frequency bands, each of them being written out and integrated separately.

In most of our E.E.G. experiments in guinea-pigs not only the E.E.G. but also the summation E.M.G. and E.C.G. were recorded. The E.C.G. records are described later in this paper.

Results In the normal E.E.G. recorded bipolarly from the motor area of a waking guinea-pig fast rhythms in the alpha and beta ranges usually dominate. Sometimes, however, a dominant frequency in the theta range may be present (Mikiska and Mikisková, I964). Examples of normal tracings are presented in Fig. 2 and in a previous paper in this journal (Mikisková and Mikiska, 1966). In some experiments we have observed short episodes of regular $14 \mathrm{c} / \mathrm{s}$ spindles, corresponding very probably to a light physiological sleep, a pattern well known for cats (Hess, Koella, and Akert, 1953) and rabbits (Gangloff and Monnier, 1956, 1957).

Nociceptive stimulation associated with intraperitoneal injection of phy:iological saline caused, in some experiments, a transitory decrease in E.E.G. amplitude, i.e., an arousal reaction. Other reflex influences of handling in an experiment lasting 4 to 6 hours did not evoke any significant change in the E.E.G. pattern or amplitude (Table III). The E.E.G. was very stable in many control experiments lasting up to several weeks, but the possibility of sudden changes, due mostly to damaged electrodes, could never be completely excluded. Therefore, 
TABLE III

Action of Some ANAesthetics (AdMinistered intraperitoneally) on the E.E.G. AMplitude in Guinea-pigs

\begin{tabular}{|c|c|c|c|c|}
\hline Compound (dose) & $\begin{array}{c}\text { Time from } \\
\text { Injection (min.) }\end{array}$ & $\begin{array}{l}\text { Percent Change } \\
\text { in E.E.G. } \\
\text { Amplitude }\end{array}$ & $P$ less than & No. of Animals \\
\hline $0.9 \%$ sol. $\mathrm{NaCl}(0.4 \mathrm{ml})$. & $\begin{array}{r}15 \\
30 \\
45 \\
60 \\
75 \\
165\end{array}$ & $\begin{array}{ll}- & 2.4 \\
- & 1.8 \\
- & 2.0 \\
- & 1.1 \\
- & 0.2 \\
+ & 1.8\end{array}$ & & $\begin{aligned} & 8 \\
\text { S.D. } & 5 \cdot 60 \\
\text { S.E.M. } & 1 \cdot 98\end{aligned}$ \\
\hline Dial (0.19 mM./kg.) & $\begin{array}{r}5 \\
10 \\
15 \\
30 \\
45 \\
60 \\
75 \\
165\end{array}$ & $\begin{array}{l}+40 \cdot 8 \\
+61.8 \\
+66.2 \\
+60 \cdot 5 \\
+63.0 \\
+65.7 \\
+64 \cdot 7 \\
+59 \cdot 3\end{array}$ & $\begin{array}{l}0.002 \\
0.002 \\
0.002 \\
0.002 \\
0.002 \\
0.002 \\
\end{array}$ & $\begin{array}{c}{ }^{4} \\
\text { S.D. } 16 \cdot 17 \\
\text { S.E.M. } \quad 8 \cdot 09\end{array}$ \\
\hline Chloral hydrate (0.84 mM./kg.) & $\begin{array}{r}5 \\
10 \\
15 \\
30 \\
45 \\
60 \\
75 \\
165\end{array}$ & $\begin{array}{l}+14.8 \\
+37.5 \\
+25.6 \\
+19.7 \\
+11.5 \\
+7.2 \\
+\quad 4.4 \\
+5.9\end{array}$ & $\begin{array}{l}0.002 \\
0.002 \\
0.002 \\
0.002\end{array}$ & $\begin{aligned} & 4 \\
\text { S.D. } & 8 \cdot 52 \\
\text { S.E.M. } & 4 \cdot 26\end{aligned}$ \\
\hline Trichloroethanol (2.2 mM./kg.) & $\begin{array}{r}5 \\
10 \\
15 \\
30 \\
45 \\
60 \\
75 \\
165\end{array}$ & $\begin{array}{r}+22.3 \\
+18.6 \\
+14.6 \\
+11.8 \\
+\quad 6.6 \\
+4.2 \\
+2.8 \\
-2.1\end{array}$ & $\begin{array}{l}0.011 \\
0.055 \\
0.055\end{array}$ & 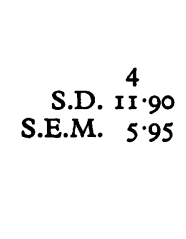 \\
\hline Trichloroethylene (6.7 mM./kg.) & $\begin{array}{r}5 \\
10 \\
15 \\
30 \\
45 \\
60 \\
75 \\
165\end{array}$ & $\begin{array}{l}-0.1 \\
+2.4 \\
+5.0 \\
+6.9 \\
+9.3 \\
+7.0 \\
+8.8 \\
+9.3\end{array}$ & $\begin{array}{l}0.085 \\
0.023 \\
0.001 \\
0.023 \\
0.001 \\
0.047\end{array}$ & $\begin{aligned} & 5 \\
\text { S.D. } & 6 \cdot 39 \\
\text { S.E.M. } & 2 \cdot 86\end{aligned}$ \\
\hline
\end{tabular}

S.D. = standard deviation; S.E.M. = standard error of mean.

the reliability of electroencephalography in longterm experiments was lower the longer the experiment.

Some quantitative results (E.E.G. integration) with depressants are given in Table III. Means of control experiments and significance levels are presented only for observations after a lapse of I5 minutes or more after the injection, when the arousal reaction due to the injection had already disappeared. Both the change in the E.E.G. amplitude and the E.E.G. pattern in light and moderate anaesthesia differed with the type of anaesthetic. Trichloroethylene and trichloroethanol, volatile anaesthetics, induced only a moderate increase in E.E.G. amplitude. Dial, a barbiturate, caused a much larger increase in E.E.G. amplitude. Chloral hydrate was in between.

Chloral hydrate influenced the E.E.G. more than trichloroethanol: $0.84 \mathrm{mM}$. $/ \mathrm{kg}$. of chloral hydrate increased the E.E.G. amplitude more than $2 \cdot 2$ $\mathrm{mM}$. $/ \mathrm{kg}$. of trichloroethanol. This finding disagrees with the view advanced by Butler (1948) and 
Marshall and Owens (1954) that chloral hydrate acts as an anaesthetic only after metabolic conversion to trichloroethanol.

For increasing the threshold of the spinal defensive reflex (Fig. 3), 6.7 mM./kg. of trichloroethylene, $0.84 \mathrm{mM}$. $/ \mathrm{kg}$. of chloral hydrate, and $0.19 \mathrm{mM} . / \mathrm{kg}$. of dial were equally effective. The doses are not equieffective on the E.E.G. There are several factors that could explain the observed differences. The most important of them seems to be the relative solubility in water and lipid phases (Mikiska, I965). The lack of correlation between the action of anaesthetic agents of various types on spinal reflex excitability and on E.E.G. amplitude shows that 'central nervous toxicity' is not a homogeneous concept but depends on the function studied.

The waveform patterns of E.E.G. were affected by these compounds, as shown in Table IV. The correlation of the patterns observed with the quantitative E.E.G. data will be discussed in the next section.

As an example of the action of inhaled solvents, the effects of carbon disulphide are shown in Figure 2. The most striking feature was a marked desynchronization of the neocortical E.E.G. lasting up to several hours after the exposure; spindles of high voltage and very irregular shape, consisting of components of various frequencies, superimposed over the flattened tracing and accompanied sometimes by trains of slow waves, were manifestations of a still deeper stage of central nervous depression (Mikisková and Mikiska, 1964).

Discussion The first work known to us on electroencephalography on animals experimentally exposed to industrial solvents was carried out in

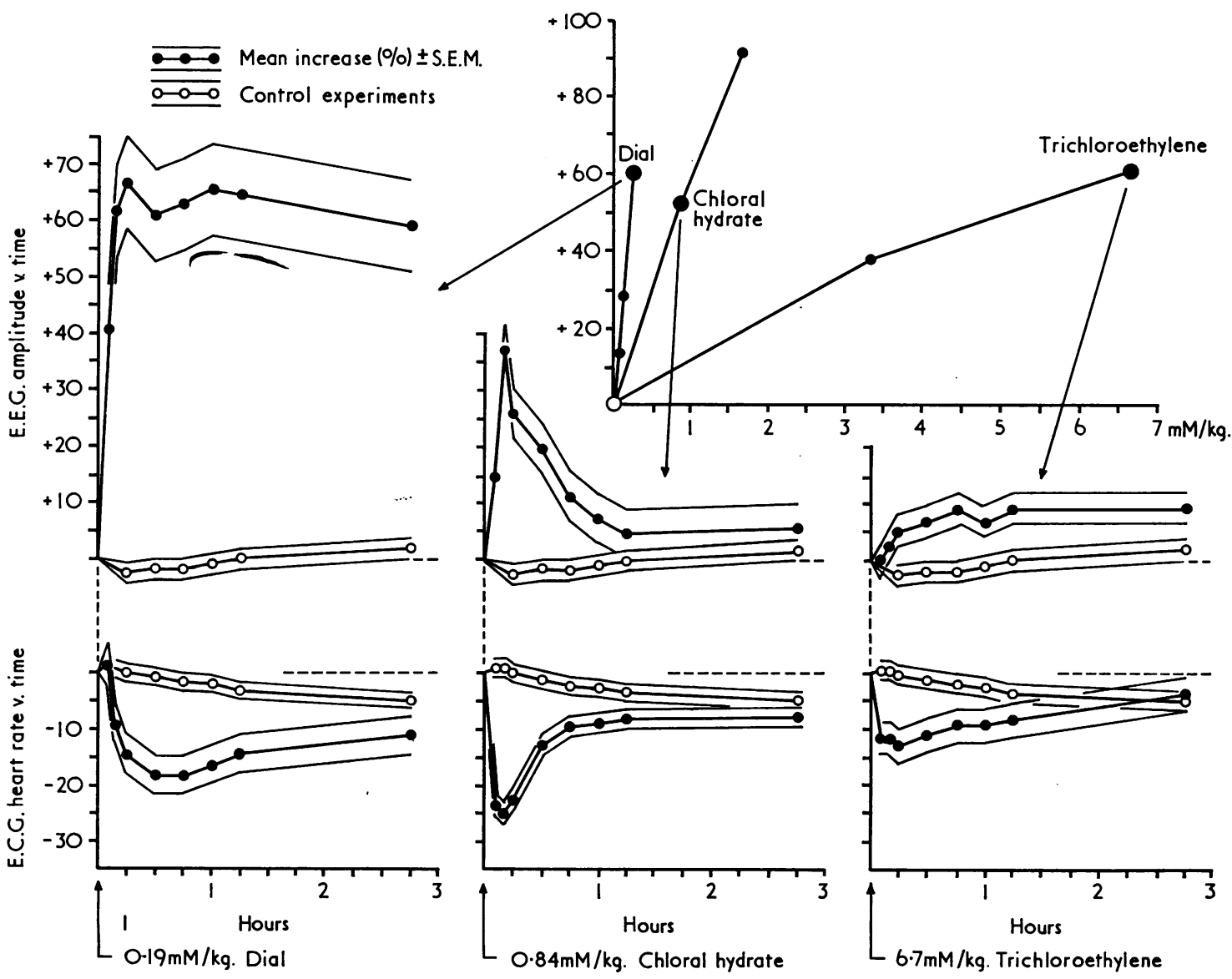

Fig. 3. Comparison of three anaesthetics of different types by means of two neurophysiological tests and E.C.G. recording. Upper right: skin stimulation threshold current $v$. dose. 
TABLE IV

\begin{tabular}{|c|c|c|}
\hline \multicolumn{2}{|c|}{ E.E.G. Pattern of Rodents' Neocortex } & \multirow{2}{*}{$\begin{array}{c}\text { Corresponding E.E.G. Stage of } \\
\text { Anaesthesia }\end{array}$} \\
\hline Water-insoluble Compounds ${ }^{1}$ & Water-soluble Compounds ${ }^{2}$ & \\
\hline $\begin{array}{l}\text { Random slow waves and/or spindles } \\
\text { (superimposed over unchanged or } \\
\text { 'desynchronized' E.E.G.) }\end{array}$ & $\begin{array}{l}\text { Random spindles (superimposed } \\
\text { over E.E.G. similar to that of the } \\
\text { alert state) }\end{array}$ & $\begin{array}{l}\text { Hypnotic effect appearing only when } \\
\text { environment conditions favour } \\
\text { falling asleep, but absent if onset of } \\
\text { anaesthesia is too rapid }\end{array}$ \\
\hline $\begin{array}{l}\text { 'Desynchronization' of E.E.G.: decrease } \\
\text { in amplitude, especially in that of } \\
\text { slower frequency components }\end{array}$ & $\begin{array}{l}\text { High-voltage fast activity ( } 14-30 \mathrm{c} / \mathrm{s} \text {, } \\
\text { particularly in the anterior regions } \\
\text { of the cerebral hemispheres) }\end{array}$ & Fast $^{3}$ \\
\hline Not observed & Not observed & $\begin{array}{l}\text { Rhythmic }{ }^{3} \\
(3-7 \mathrm{c} / \mathrm{s} \text { regular E.E.G. activity) }\end{array}$ \\
\hline $\begin{array}{l}\text { Continuous high-voltage slow waves } \\
\text { and/or spindles }\end{array}$ & $\begin{array}{l}\text { Continuous spindles and high- } \\
\text { voltage slow waves }\end{array}$ & $\begin{array}{l}\text { Complex } \\
\text { (E.E.G. pattern similar to sleep } \\
\text { stages C, D, E or to E.E.G. of } \\
\text { 'cerveau isolé' preparations) }\end{array}$ \\
\hline \multicolumn{2}{|c|}{$\begin{array}{l}\text { Bursts of E.E.G. waves of moderate to high voltage alternating with sections of } \\
\text { low-voltage, predominantly slow, electrical activity }\end{array}$} & Burst-suppression ${ }^{3}$ \\
\hline \multicolumn{2}{|c|}{ Low-voltage, predominantly slow, electrical activity only } & Suppression $^{3}$ \\
\hline
\end{tabular}

${ }^{1} \mathrm{Lipid}$ solvents and volatile anaesthetics.

${ }^{2}$ Barbiturates and chloral hydrate.

${ }^{3}$ Classification of Martin, Faulconer, and Bickford (1959).

our Institute and reported by Horváth and Michalová (1952, 1956). A decrease in the E.E.G. amplitude of the optic and motor area of the rabbit's neocortex was observed after inhalation of carbon disulphide. After repeated exposure occasional low-voltage theta activity appeared. These changes were not accompanied by any striking behavioural ones. Later, Horváth and Mikiska (1957) stated that in rabbits with implanted electrodes in the diencephalon a regular theta rhythm followed carbon disulphide administration, and that this disappeared only after considerable overdosage, eventually resulting in the rabbit's death. In the same paper exposure to trichloroethylene vapours was reported to evoke anaesthetic patterns comparable to those following intravenous barbiturate administration. Another early paper in this field was that by Andersen and Kaada (1953) on the action of a toluene-butyl acetate mixture on the rabbit's neocortex.

A drawback common to all these early observations was the overestimation of the similarity between the observed E.E.G. pattern with clinical findings in poisoned humans and even with E.E.G. abnormalities of other than toxic origin. The same is, however, true for most pharmacological studies from that period (see the reviews by Toman and
Davis (1949), Greville and Heppenstall (1950), Schneider (1954), and Verdeaux and Marty (1954)). Better understanding of mechanisms of action has arisen only from the analytical electrophysiological work of, for example, French, Verzeano, and Magoun (1953), Brazier (1954), Arduini and Arduini (1954), Domino (1955), and King (1956); but these authors paid little attention to the spontaneous E.E.G. pattern.

Many of the more recent experimental papers on the E.E.G. of animals given industrial solvents are descriptive, so that it is difficult to decide whether different E.E.G. patterns should be attributed to differences in the action of tested compounds or only to different degrees of central nervous depression. This is particularly true when the toxic vapour concentration was neither controlled nor measured. A review on trichloroethylene was published in our previous paper (Mikisková and Mikiska, 1966). For other solvents, very thorough reviews may be found, e.g., in the monograph by Serra and Ambrosio (I96I) or in the review article by Higashida (1964).

Table IV represents an attempt to provide a comparison of the E.E.G. patterns observed in our experiments (having appeared, at least in some of 
them, as a regular sequence of defined stages) with the general E.E.G. stages of anaesthesia as described by Martin and his colleagues (1959) and further used for classification by Faulconer and Bickford (I96I). This classification seems to us to be a suitable basis of comparison, because of the following features:

(I) It stresses the similarity between the E.E.G. patterns found in the various species and brain structures, which is the more striking the deeper the anaesthesia.

(2) It is not confused with the stages and planes of anaesthesia according to the depression of reflexes and autonomic functions, e.g., as described by Guedel (I95I).

(3) It is partly based on the mean E.E.G. amplitude, i.e., a quantitative result.

In light and moderate anaesthesia, Martin et al.'s (1959) classification on its own was not completely satisfactory. Table IV attempts, therefore, to specify the difference in E.E.G. patterns for waterinsoluble and water-soluble anaesthetics. The observed differences seem to be closely related to different mean E.E.G. amplitude increases. Watersoluble anaesthetics, particularly barbiturates, are characterized by the high amplitude of the fast rhythms which they evoke in the rodents' neocortex, both in the 'fast' and 'complex' stages of anaesthesia. No acceptable neurophysiological explanation of this difference has been suggested, as far as we know. It is, however, certain that both high-voltage fast activity in light barbiturate anaesthesia (Shimazono, Okuma, Fukuda, Hirai, and Yamamasu, I953; Chafetz and Cadilhac, I954) and low-voltage fast activity of the E.E.G. desynchronized by volatile anaesthetics (Rossi and Zirondoli, 1955; Schlag and Brand, 1958) disappear after any suppression of the activating influences ascending from the mesencephalic reticular formation.

We hope that the data in Table IV can serve as a guide for the classification of E.E.G. patterns in light anaesthesia to those who intend to use a recording technique similar to that described in this paper. A more detailed electroencephalographic analysis should also include data on the E.E.G. pattern of rhinencephalic and subcortical structures as well as some characteristic kinds of evoked activity.

Evoked E.E.G. activity or analysis of spontaneous E.E.G. have been used only exceptionally for testing the action of industrial solvents in laboratory animals. Higashida (I964) studied the action on various types of activity evoked by electrical brain stimulation by the techniques worked out by Longo (1962). Unfortunately, only the abstracts are available in English. Dési and Nikolits (1967) have demonstrated the central nervous action of benzene and xylene by studying their action on spike discharge following local application of strychnine to the cat's neocortex. In another paper on the E.E.G. of rats poisoned with benzene Dési (I967) examined the effect on the desynchronization response to electrical stimulation of the occipital neocortex. The spontaneous E.E.G. was analysed in these animals by multichannel spectral and autocorrelation techniques.

Conclusions The E.E.G. gives information on the functional state of the central nervous system from its bioelectrical activity. Recorded waveform patterns change in a characteristic manner under the influence of various drugs. Besides these rather qualitative characteristics, E.E.G. data can be evaluated quantitatively by analysis of the mean voltage, frequency spectrum, etc.

Reproducible E.E.G. changes were measured for several hours after a reflex response had elapsed. In studies of chronic toxicity, however, the reliability was lower. E.E.G. findings in animals often resemble clinical observations, suggesting that the mechanism of action is similar. The specificity of E.E.G. patterns with respect to various physiological conditions and toxic factors should not, however, be overestimated. Simultaneous recording of the bioelectrical activity of other organs contributes to an effective exploitation of the necessary electronic equipment and, in many cases also, to better understanding of the mechanisms of action of the compounds studied.

\section{Electrocardiographic Examination}

Electrocardiography is an electrophysiological technique that may be of interest to pharmacologists and toxicologists for several reasons: (I) It supplements neurophysiological methods by providing data on the central nervous control of autonomic: functions. (2) It enables the pharmacodynamic: effects to be studied on an excitable tissue whose cyclic excitability changes can be examined more readily than those of the central nervous system.

The complex pattern of the E.C.G. may be analysed in three ways:

(I) By gross examination of the regularity of the heart rhythm, and of the intrinsic cardiac pacemaker, and by counting the average heart rate.

(2) By determination of the time parameters, e.g., pulse intervals (RR), atrioventricular conduction time (PQ), duration of the depolarization 
(QRS), and repolarization (ST) phases of the electrical heart systole, etc.

(3) By voltage measurement, i.e., by estimating the amplitude and polarity of the E.C.G. waves; and by ascertaining the elevation or depression of the ST segment.

The first and second types of analysis can be performed with a high degree of reliability from any single E.C.G. lead. Although the possibility that an E.C.G. wave is isoelectric in a particular lead can never be excluded, the probability of such an event is small, especially if we examine thoroughly several E.C.G. complexes corresponding to various phases of respiration.

For voltage measurement, however, an E.C.G. lead is of little value. It is necessary to record at least three independent E.C.G. leads, e.g., those corresponding to the axes of a Cartesian coordinate system: $\mathrm{X}, \mathrm{Y}$, and $\mathrm{Z}$.

For evaluation of the E.C.G., the animal's emotional stress due to the examination procedure should not be ignored. The demands of a very detailed examination and of minimal stress are often conflicting. For this reason, we have tested three techniques of E.C.G. recording.

\section{Recording Techniques}

(I) From Animals tied to a Fixation Table This technique is suitable both for screening or pilot experiments and as a part of detailed examinations, including E.C.G. voltage measurement or simultaneous recording of other bioelectric data (E.E.G., E.M.G.).

The animal was fixed to a fixation table. Electrodes for the leads to the extremities were made from alligator clips by soldering two silver plates to the jaws in order to reduce the pressure on the skin by increasing the contact area. Before applying them the skin was shaved and covered with electrocardiographic paste. Inter-electrode resistance below to kilohms ensures, as a rule, artefactfree recording, except during gross movement.

To obtain data on the magnitude and direction of the electrical heart vector (dipole moment), the lead system proposed by Wilson, Johnston, and Kossmann (I947) appeared to be the most convenient. No system of leads proposed for spatial vectorcardiography is perfect, but Burch, Abildskov, and Cronvich (1953) have reported that Wilson's system was not inferior, for determining the absolute vector direction in humans or dogs, to any other system based on fixed reference points (needing no special examination of the individual's thorax). In rodents, such evidence is lacking. For this reason, only relative changes in vector were evaluated in our experiments, in order to discriminate changes in E.C.G. wave amplitudes due to the pharmacodynamic effect from changes due only to heart rotation.

If, for example, a decrease in the amplitude or inversion of the polarity of the $T$ wave occurs in all leads, this result indicates a pharmacodynamic effect (suggestive, in this case, of myocardial anoxia). A similar pattern in one lead only may not be significant. A schematic diagram of E.C.G. leads is shown in Figure 4. Three extremity electrodes, $R, L$, and F, correspond to those of Einthoven's triangle. The back electrode, B, cannot be localized in animals in relation to the skeleton with the same degree of accuracy as in humans. It is therefore positioned in the dorsal projection of maximum heart apex stroke (in guinea-pigs, approximately $\mathrm{I} \mathrm{cm}$. to the left of the midline). A small disc electrode filled with paste and fixed with collodion or adhesive tape is used, e.g., a standard type for human scalp electroencephalography.

Examples of three-dimensional E.C.G. records have been presented in a previous paper in this journal (Mikisková and Mikiska, 1966).

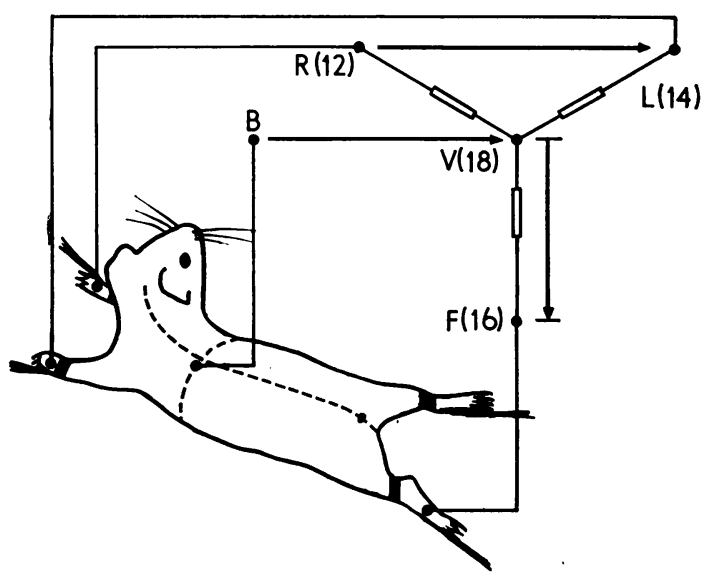

FIG. 4. Schematic diagram of the three-dimensional system of E.C.G. leads. (Numbers in parentheses denote input plugs of the recorder.)

(2) From Freely Moving Animals Electrodes, consisting of silver plates of $8 \mathrm{~mm}$. diameter embedded in plexiglass bodies, were used for recording. The contact area of skin was shaved and depilated, and the electrode was filled with paste and fixed with collodion. Cable leads were attached by nuts. (The same type of electrode is also used for radio-telemetric transmission.)

In guinea-pigs, electrodes were best placed on the head vertex and on the back over the sacral bone. The E.C.G. waveform did not greatly differ from lead aVF-a distortion by electromyographic potentials occurs only during gross movements. On rabbits, it was better to place the anterior electrode over the lower part of the cervical vertebral column to thwart the animal's attempts to pull the electrode down, even though it gave lower E.C.G. voltages and greater E.M.G. distortion.

After the reliability of fixation and interelectrode resistance had been checked, the animal was returned to its own cage (without lid), and a two-lead, thin, flexible cable, attached to the electrodes, was fixed by 
insertion into the input plugs of the recorder, placed approximately $\mathrm{I} \mathrm{m}$. above the animal. The cable length was adjusted so that it did not form too loose a loop.

In guinea-pigs the reliability of E.C.G. recording in a six-hour experiment was more than $90 \%$.

(3) By Radio Telemetry The same construction and localization of electrodes as was used in (2) was suitable also for wireless radio-telemetric transmission of the E.C.G. The transmitter was fixed on the animal's back by four tapes, the anterior ones forming loops passing under the shoulders, and the hind ones joined beneath the animal's belly by a broad, very soft rubber band.

Radio telemetry has three principal advantages: (I) It provides nearly full reliability of recording, no matter where the animal moves in the laboratory. (2) It eliminates the necessity for any special precautions against mains pick-up or other external interfering potentials. (3) The E.C.G. can be telemetered from hermetically sealed exposure chambers.

In a typical toxicological experiment we exposed the animal first of all to a stream of pure air and only after at least the 30 minutes required for the animal to adapt to its new environment was the supply of toxic vapour switched on. When the exposure was discontinued, the animal was left in the chamber so that recovery could be followed up without any handling (Figs 5 and 6).

In order to prevent radio-frequency interference caused by sparking of motors, switches, and other heavy-current equipment, especially that included in the exposure apparatus, we chose a double-frequency modulation system of radio telemetry, using an F.M.subcarrier frequency. The schematic diagram presented in Fig. 7 shows the general arrangement of the telemetry system. The transmitter had no radiating antenna, so that its radius of action was limited to rO-I5 metres. The distance to the recording site could nevertheless be substantially greater when the receiving dipole was located in the same room as the exposure equipment and the signal was led to the receiver by a coaxial cable. A conventional F.M.-broadcast tuner was used for receiving, as the limitation of the signal amplitude can be easily achieved in the demodulator circuit. After passing a band-pass frequency filter and amplitude limiter, the sub-carrier frequency was (I) demodulated for recording and/or on-line analysis, (2) amplified for auditory monitoring, and (3) led to a magnetic tape recorder, providing the possibility for further automatic signal processing.

The E.C.G. transmitters were designed and built in our laboratory from the 'human' model described in a

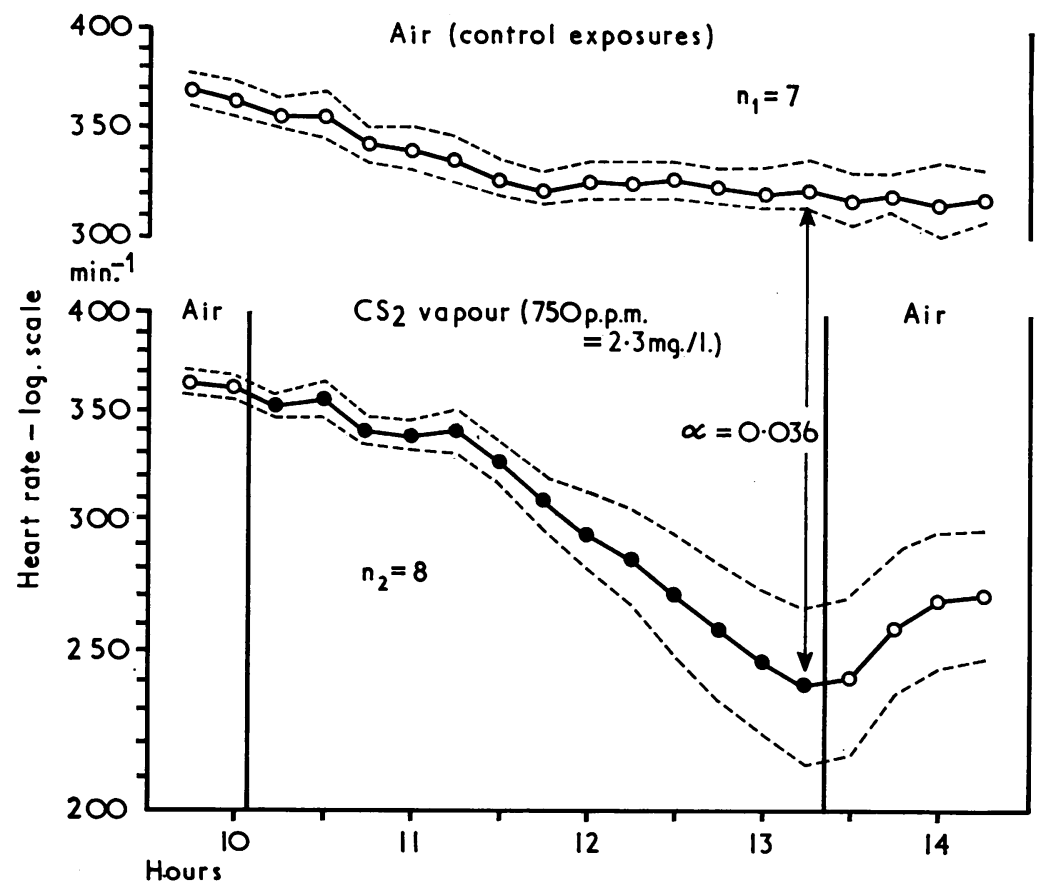

Fig. 5. Effects on the heart rate of the exposure of guinea-pigs to carbon disulphide, measured with radio-telemetric E.C.G. transmission from within the exposure chamber.

mean rates in controls; mean rates during exposure to carbon disulphide.

-- \pm S.E.M. $n_{1}, n_{2}=$ numbers of animals.

$\alpha=$ level of significance at the maximum toxic effect. 
- $10 h .00 m$ m. $\left(345 \min ^{-1}\right)$

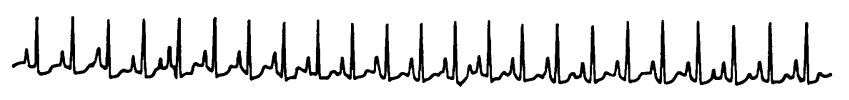

- 13h.OOm. (155min-1) 750p.p.m.CS2 (10h.O 5m.-13h.2Om.)

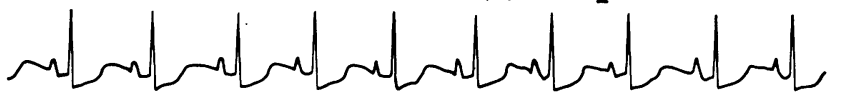

- $14 \mathrm{~h} .15 \mathrm{~m} .\left(168 \mathrm{~min}^{-1}\right)$

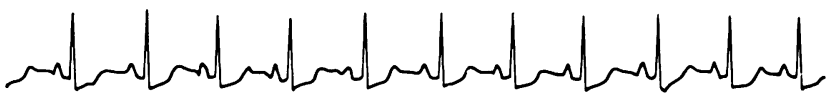

$(0.5 \mathrm{mV}, 1.0 \mathrm{sec}$.

FIG. 6. Examples of guinea-pig's E.C.G. telemetered from within the exposure chamber.

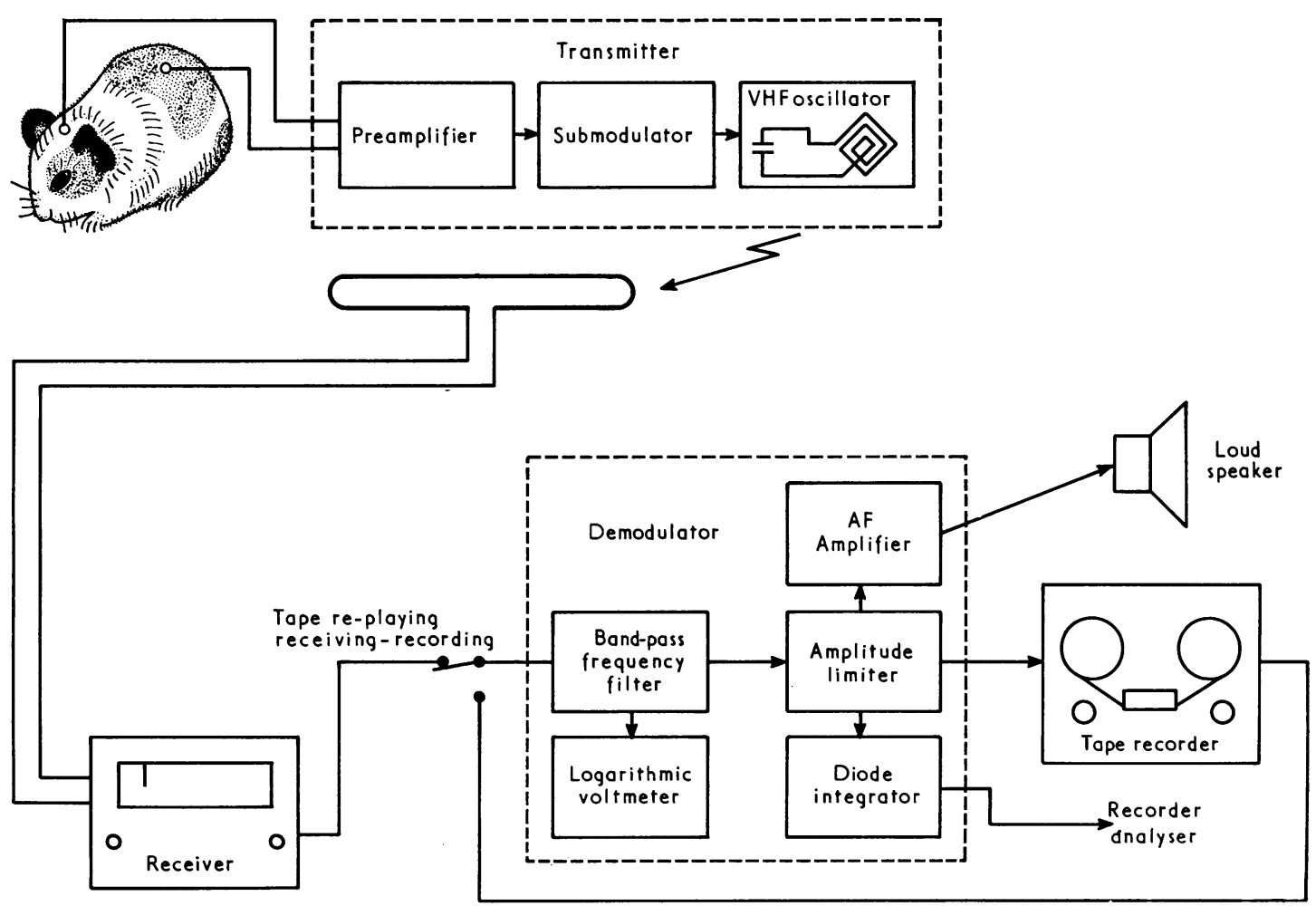

FIG. 7. Schematic diagram of the radio telemetry-magnetic tape recording system. 
previous paper (Mikiska, 1967). They differ only in that no shunting and coupling capacitors larger than $20 \mu \mathrm{F}$ were used and that two mercury cells served as the power supply.

Results For the quantitative estimation of pharmacodynamic action the most important characteristics are the presence or absence of gross irregularities of rhythm in the intrinsic cardiac pacemaker and the average heart rate (beats/min.). The heart rate of a guinea-pig can be determined from a one-minute count with an accuracy greater than $0.5 \%$. The duration of the QRS complex, 0.025 to $0.050 \mathrm{sec}$., recorded at a paper speed of $60 \mathrm{~mm}$./sec., represents a length of only $\mathrm{I} \cdot 5$ to $3.0 \mathrm{~mm}$. and is a semiquantitative rather than a quantitative E.C.G. characteristic. Other E.C.G. parameters should be regarded as supplementary data, although they can sometimes contribute greatly to an analysis of the mechanism of action. An example is shown in Figure 6.

It is difficult to characterize the 'normal' heart rate in a given species by one number or by minimal and maximal values only. Among factors affecting the heart rate in untreated laboratory animals, age and emotional state seem to be the most important.

The nomogram in Fig. 8 summarizes heart rates in guinea-pigs tied to a fixation table, determined in 53 males of different ages. Each animal received two prior training sessions to accustom it to handling. For most animals mean values from three recording sessions were used to compute the linear regression of rate against weight. Weight was used instead of age because the age was not always known accurately, as the guinea-pigs were supplied from breeding farms.

Figure 8 also shows how individual values were distributed about their means, and can be used to 'standardize' the animal population with respect to the heart rate. If one aims to reduce interindividual variability, animals with heart rates near the mean can be chosen, e.g., those whose heart rates lie between the $25 \%$ and $75 \%$ percentage points.

In female guinea-pigs tied to a fixation table, heart rates consistent with those in Fig. 8 were found. Heart rates of young animals weighing more than $300 \mathrm{~g}$. also fit the nomogram.

In less than $5 \%$ of the guinea-pigs tied to a fixation table a marked cardiac arrhythmia was found. Mostly it was only a sinus arrhythmia, apparently not related to respiratory rhythm. More rarely there were randomly occurring ventricular extrasystoles. Other types of rhythm irregularities were observed only exceptionally and can be regarded as pathological (transient complete atrioventricular block, grouped ventricular extrasystoles, etc.).

The E.C.G. waveform observed in guinea-pigs bore a striking resemblance to human records, unlike the E.C.G. of smaller laboratory rodents such as mice, rats or hamsters. The QRS complex was usually diphasic and can be designated 'RS'type, the first deflection being of higher voltage in most leads. In the extremity leads, as a rule, the

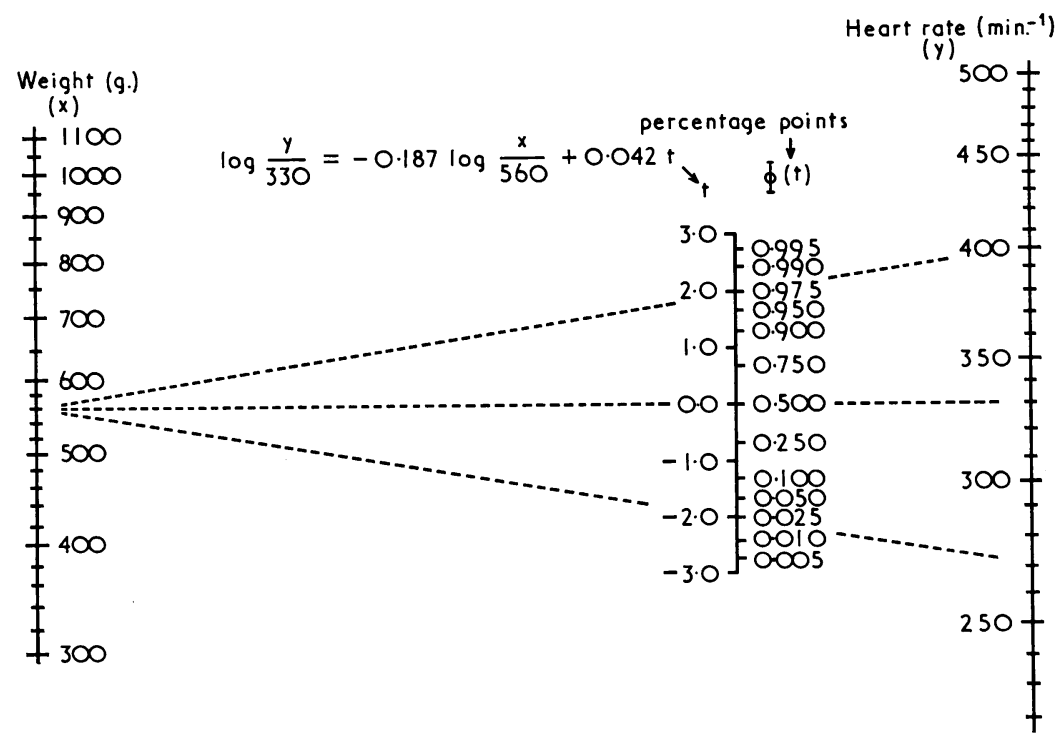

Fig. 8. Nomogram of 'normal' heart rate values in fixed male guinea-pigs. 
polarity of deflections corresponded to the standard position of the heart axis in the human E.C.G. A distinct isoelectric ST interval of at least $0.05 \mathrm{sec}$. duration, and elevated or depressed usually by not more than $0.05 \mathrm{mV}$, was an outstanding feature of the guinea-pig's E.C.G. which was absent in smaller rodents. On the other hand, the $T$ wave was often of low voltage, even lower than $0.1 \mathrm{mV}$, and sometimes diphasic, the first phase being of opposite polarity to the $R$ wave. A monophasic $T$ wave of a polarity opposite to that of the $R$ wave, occurring in all E.C.G. leads at once, was, however, exceptional in untreated animals.

The rabbit's E.C.G., too, resembled the human's in the same ways, but the ST interval often deviated from the isoelectric line by more than $0.1 \mathrm{mV}$.

The effects of handling are illustrated by the following examples. In two groups of animals the results of three experimental procedures were compared: (I) recording in animals tied to a fixation table, first continuously for 4 hours, then only for the several minutes necessary to record the E.C.G. at the end of the fifth and sixth hours; (2) E.C.G. radio telemetry from within a quiet laboratory; and (3) E.C.G. recording by means of a wire connexion with recorder input, the animal being unrestrained in its own cage and the experimenter absent. Table $\mathrm{V}$ presents mean heart rates and estimates of the standard error of the mean. Values were converted to logarithms before processing, so the means are the geometric ones, for comparison with the nomogram in Figure 8.

While in the tied guinea-pig the heart rate remained remarkably constant during a six-hour experiment, the heart rate in freely moving animals gradually slowed, especially in those with wire connexions, which obviously impose less stress than the carrying of a transmitter. However, in unrestrained guinea-pigs in a quiet environment the incidence of sinus arrhythmias greatly increased. Arrhythmias of other types remained rare. In rabbits under similar conditions the decrease in heart rate was less regular, but cardiac arrhythmias, including those originating from atrioventricular block, were observed more often than in guinea-pigs.

Experiments with injection of physiological saline showed that intraperitoneal administration caused only very small changes in the heart rate even as early as 5 minutes after the injection (Table VI).

The results with some anaesthetics are summarized in Table VI. The drugs were administered in doses causing light or moderate anaesthesia. A significant decrease in the heart rate was observed after all the compounds tested. A comparison of the results with those of tests of central nervous depressants (Tables I, II, and III) shows that for all the compounds tested the measurement of the heart rate was about as sensitive as the neurophysiological tests.

Other E.C.G. results were similar to those described for trichloroethylene and trichloroethanol (Mikisková and Mikiska, 1966)—slowing of the atrioventricular transmission of excitation, i.e., lengthening of the $P Q$ interval, and lengthening of the repolarization phase of the electrical systole of the ventricles, i.e., of the ST interval.

More complicated E.C.G. patterns have been observed in guinea-pigs after exposure to carbon disulphide. Their general features were published in a pilot study (Mikisková and Mikiska, 1964). In order to assess the statistical significance of the observations, a second experimental series was

TABLE V

Heart Rate of Male Guinea-pigs in Different Test Situations

\begin{tabular}{|c|c|c|c|c|c|c|c|c|c|c|}
\hline \multirow{2}{*}{ Test Situation } & \multicolumn{7}{|c|}{ Time from Starting Experiment (hours) } & \multirow{2}{*}{$\begin{array}{l}\text { Relative } \\
\text { S.E.M. } \\
(\%)\end{array}$} & \multirow{2}{*}{$\begin{array}{c}\text { No. of } \\
\text { Experiments }\end{array}$} & \multirow{2}{*}{$\begin{array}{l}\text { No. of } \\
\text { Animals }\end{array}$} \\
\hline & 0 & $\boldsymbol{I}$ & 2 & 3 & 4 & 5 & 6 & & & \\
\hline $\begin{array}{l}\text { Younger animals } \\
\text { Tied to fixation table } \\
\text { Carrying transmitter } \\
\text { Unrestrained wire connexion }\end{array}$ & $\begin{array}{l}362 \\
368 \\
343\end{array}$ & $\begin{array}{l}366 \\
352 \\
290\end{array}$ & $\begin{array}{l}360 \\
330 \\
270\end{array}$ & $\begin{array}{l}357 \\
325 \\
265\end{array}$ & $\begin{array}{l}355 \\
320 \\
251\end{array}$ & $\begin{array}{l}354 \\
320 \\
249\end{array}$ & $\begin{array}{l}355 \\
243\end{array}$ & $\begin{array}{l} \pm I \cdot I \\
\pm 2 \cdot 6 \\
\pm 2 \cdot 0\end{array}$ & $\begin{array}{r}18 \\
7 \\
18\end{array}$ & $\begin{array}{l}6 \\
7 \\
6\end{array}$ \\
\hline $\begin{array}{l}\text { Older animals }{ }^{2} \\
\text { Tied to fixation table } \\
\text { Carrying transmitter } \\
\text { Unrestrained wire connexion }\end{array}$ & $\begin{array}{l}323 \\
304 \\
297\end{array}$ & $\begin{array}{l}321 \\
275 \\
274\end{array}$ & $\begin{array}{l}316 \\
276 \\
255\end{array}$ & $\begin{array}{l}309 \\
270 \\
251\end{array}$ & $\begin{array}{l}309 \\
272 \\
244\end{array}$ & $\begin{array}{l}311 \\
266 \\
242\end{array}$ & $\begin{array}{l}304 \\
264 \\
234\end{array}$ & $\begin{array}{l} \pm \mathrm{I} \cdot 8 \\
\pm 2 \cdot 3 \\
\pm 2 \cdot 2\end{array}$ & $\begin{array}{l}18 \\
18 \\
18\end{array}$ & $\begin{array}{l}6 \\
8 \\
6\end{array}$ \\
\hline
\end{tabular}

${ }^{1}$ Age 2-4 months, weight 330-580 g.

${ }^{2}$ Age 12-18 months, weight 800-1,100 g. 
Some Electrophysiological Methods for Studying the Action of Narcotic Agents in Animals

TABLE VI

Action of Some ANAesthetics (administered INTRAperitoneally) on Heart Rate in Guinea-Pigs tied to a Fixation Table

\begin{tabular}{|c|c|c|c|c|}
\hline Compound (dose) & $\begin{array}{c}\text { Time from } \\
\text { Injection (min.) }\end{array}$ & $\begin{array}{c}\text { Change in Rate } \\
(\%)\end{array}$ & Significance & No. of Animals \\
\hline $0.9 \%$ sol. $\mathrm{NaCl}(0.4 \mathrm{ml})$. & $\begin{array}{r}5 \\
10 \\
15 \\
30 \\
45 \\
60 \\
75 \\
165\end{array}$ & $\begin{array}{r}+0.5 \\
+0.5 \\
0.0 \\
-0.9 \\
-1.7 \\
-\quad 2.1 \\
-\quad 3.0 \\
-4.9\end{array}$ & & $\begin{array}{cc}\text { IO } \\
\text { S.D. } & 3.1 \mathrm{I} \\
\text { S.E.M. } & 0.99\end{array}$ \\
\hline Dial (0.19 mM./kg.) & $\begin{array}{r}5 \\
10 \\
15 \\
30 \\
45 \\
60 \\
75 \\
165\end{array}$ & $\begin{array}{l}+1.4 \\
-9.5 \\
-14.4 \\
-18.2 \\
-17.9 \\
-16.0 \\
-14.3 \\
-10.9\end{array}$ & $\begin{array}{l}0.002 \\
0.001 \\
0.001 \\
0.001 \\
0.002\end{array}$ & $\begin{array}{c}\text { Io } \\
\text { S.D. } 10 \cdot 17 \\
\text { S.E.M. } \\
3 \cdot 22\end{array}$ \\
\hline Chloral hydrate (0.84 mM./kg.) & $\begin{array}{r}5 \\
10 \\
15 \\
30 \\
45 \\
60 \\
75 \\
165\end{array}$ & $\begin{array}{l}-23 \cdot 1 \\
-25 \cdot 1 \\
-22 \cdot 2 \\
-12 \cdot 4 \\
-9 \cdot 2 \\
-8 \cdot 7 \\
-8 \cdot 3 \\
-7 \cdot 2\end{array}$ & $\begin{array}{l}0.001 \\
0.001 \\
0.001 \\
0.001 \\
0.001 \\
0.001 \\
0.001\end{array}$ & $\begin{array}{ll}\text { S.D. } & 4 \\
\text { S.E.M. } & 3 \cdot 54 \\
1 \cdot 77\end{array}$ \\
\hline Trichloroethanol (2.2 mM./kg.) & $\begin{array}{r}5 \\
10 \\
15 \\
30 \\
45 \\
60 \\
75 \\
165\end{array}$ & $\begin{array}{l}-18.3 \\
-20.8 \\
-20.1 \\
-I 9.4 \\
-I 8.9 \\
-17.0 \\
-I 5.2 \\
-I 1.8\end{array}$ & $\begin{array}{l}0.001 \\
0.001 \\
0.001 \\
0.002 \\
0.001 \\
0.001 \\
0.002 \\
0.050\end{array}$ & $\begin{array}{c}6 \\
\text { S.D. } 13 \cdot 22 \\
\text { S.E.M. } \quad 5 \cdot 40\end{array}$ \\
\hline Trichloroethylene (6.7 mM./kg.) & $\begin{array}{r}5 \\
10 \\
15 \\
30 \\
45 \\
60 \\
75 \\
165\end{array}$ & $\begin{array}{l}- \text { II.4 } \\
\text { - II.3 } \\
\text { - I } 2.5 \\
\text { - I0.7 } \\
-9.4 \\
-9.6 \\
-7.9 \\
-4.3\end{array}$ & $\begin{array}{l}0.005 \\
0.005 \\
0.010 \\
0.025 \\
0.025 \\
0.025 \\
0.050\end{array}$ & $\begin{aligned} & 6 \\
\text { S.D. } & 8 \cdot 67 \\
\text { S.E.M. } & 3.54\end{aligned}$ \\
\hline Tetrachloroethylene (6.7 mM./kg.) & $\begin{array}{r}5 \\
10 \\
15 \\
30 \\
45 \\
60 \\
75 \\
165\end{array}$ & $\begin{array}{l}-20.3 \\
-18.7 \\
-17.3 \\
-14.9 \\
-12.6 \\
-12.5 \\
-12.8 \\
-12.0\end{array}$ & $\begin{array}{l}0.001 \\
0.001 \\
0.001 \\
0.001 \\
0.001 \\
0.001 \\
0.001 \\
0.025\end{array}$ & 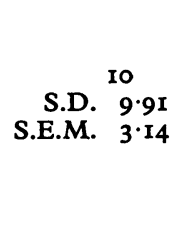 \\
\hline
\end{tabular}

S.D. = standard deviation; S.E.M. = standard error of mean. 
TABLE VII

action of Carbon Disulphide on the Heart Rate in Guinea-pigs

\begin{tabular}{|c|c|c|c|c|c|c|}
\hline \multicolumn{3}{|c|}{ Exposure } & \multicolumn{2}{|c|}{ Heart Rate ${ }^{1}$} & \multirow{2}{*}{$\begin{array}{l}\text { No. of } \\
\text { Animals }\end{array}$} & \multirow{2}{*}{ Significance } \\
\hline $\begin{array}{r}\text { Cor } \\
\text { (p.p.m.) }\end{array}$ & encentration & $\begin{array}{c}\text { Duration } \\
(\text { hrs })\end{array}$ & $\begin{array}{c}\text { Mean } \\
(\%)\end{array}$ & S.E.M. & & \\
\hline 375 & Controls & $\begin{array}{l}3 \\
3\end{array}$ & $\begin{array}{l}92 \cdot 4 \\
95 \cdot 5\end{array}$ & $\begin{array}{l} \pm 5 \cdot 3 \\
\pm 2 \cdot 3\end{array}$ & $\begin{array}{l}8 \\
8\end{array}$ & N.S. \\
\hline 375 & Controls & $\begin{array}{l}6 \\
6\end{array}$ & $\begin{array}{l}85 \cdot 9 \\
95 \cdot 5\end{array}$ & $\begin{array}{l} \pm I \cdot 8 \\
\pm 3 \cdot 3\end{array}$ & $\begin{array}{l}16 \\
16\end{array}$ & 0.050 \\
\hline 750 & Controls ${ }^{2 \cdot 3}$ & $\begin{array}{l}3 \\
3\end{array}$ & $\begin{array}{l}78 \cdot 8 \\
95 \cdot 7\end{array}$ & $\begin{array}{l} \pm 4 \cdot 7 \\
\pm I \cdot 9\end{array}$ & $\begin{array}{l}6 \\
6\end{array}$ & 0.002 \\
\hline
\end{tabular}

${ }^{1}$ Heart rate after exposure is expressed as percentage of the value before exposure.

performed (Table VII), in which groups of control animals were exposed simultaneously to pure air. The heart rate was measured both before the exposure and with the shortest possible delay (approximately 5 minutes) after removal from the exposure chamber.

A third series of experiments followed the time course of poisoning and recovery during and after exposure to carbon disulphide vapour (750 p.p.m. for 3 hours) (Fig. 5). The heart rate only began to slow 90 minutes after the start of carbon disulphide administration. Recovery was very slow, too. The E.C.G. showed both the signs common to other anaesthetics and sometimes also the displacement of the ST interval, increased duration of $P, R$, and $T$ waves, and higher degrees of atrioventricular block (Wenckebach's periods or even atrioventricular dissociation) (see e.g., Fig. 6). Sometimes both the amplitude and duration of the $T$ wave were increased, while the ST interval was shortened or absent. These changes were probably caused by irritation of the respiratory mucosae and disappeared soon after the animal breathed pure air, although recovery of the heart rate to pre-exposure values was only gradual. Unlike the other compounds tested, carbon disulphide affected the E.C.G. while causing only a slight degree of central nervous depression. After 3 hours' exposure to 750 p.p.m. the animals remained responsive and were able to walk; and the E.E.G. pattern corresponded to the desynchronization stage, but sometimes with random spindles and/or slow waves superimposed, i.e., to a light stage of anaesthesia (Fig. 2).

Discussion The information on heart action obtained from a short section of the E.C.G. tracing may be invalid and not representative. For this reason, probably, electrocardiography has not yet become a popular test of toxicity, and is used, if at all, only once on a patient, usually after the termination of subacute or chronic exposure. From this procedure only gross abnormalities of the E.C.G. can be observed. Moreover, current opinion is that E.C.G. recording in laboratory animals is tedious. We think, however, that with adequate recording, electrocardiography may help to solve many toxicological and pharmacological problems.

The literature concerning E.C.G. recording in guinea-pigs will be briefly reviewed. The use of anaesthesia for recording the E.C.G. (Lombard, 1952), drastic restraint of the animal (Pratt, 1938) or keeping it in an unnatural posture (Bartmann and Reinert, 1952) seem only to be necessary for special purposes, such as the examination of all the standard chest leads. The technique of Lukoschek and Thiesen (1954), who fastened the electrodes to the paws of manually restrained guinea-pigs, is quite suitable for short-term recording. The apparatus described by Richtarik, Woolsey, and Valdivia (I965) permits both short- and long-term recording of the E.C.G. from an unanaesthetized guinea-pig in the normal standing position; movements are restricted by a removable box, on the base of which are the electrodes (R, L, F, and earth).

We found no references to E.C.G. recording in freely moving guinea-pigs by means of either wire or radio-telemetric transmission and have therefore devoted our attention to working out suitable techniques useful, for example, for studying the interaction between drugs and physiological sleep, for which emotional stress of the animal due to the examination must be reduced to a minimum.

By using radio telemetry we could also record 
from within sealed exposure chambers, which was important:

(I) for studying the action of low concentrations of poison during which the animal should not be handled, as this may interfere with the manifestation of intoxication;

(2) during exposure to high concentrations or to compounds for which there was inadequate information on toxicity. In the latter case, continuous monitoring enabled us to prevent death from heart failure and to carry out further examination during its recovery or to attempt experimental therapy.

The mean heart rate of guinea-pigs is reported to be 245 to 327 beats per minute. Richtarik and his colleagues (1965) have reviewed other time parameters. The agreement between authors on the heart rate is quite good. The differences may be attributed to differences in age, weight, and handling during recording, to which most authors paid no attention. There is little agreement, however, on the E.C.G. wave duration. To measure this with satisfactory accuracy recording techniques capable of handling frequencies of several hundred $\mathrm{c} / \mathrm{s}$ would be required.

In our experiments interindividual variability was reduced by taking into account the handling associated with recording (Table V) and the animal's weight (Fig. 8).

The gradual slowing of the heart rate in freely moving guinea-pigs alone in a quiet environment clearly demonstrated that the heart rate of a fixed animal, although reproducible, does not represent its 'basal' value. Further experiments (to be published) have confirmed that tying prevented the animal's heart rate from slowing. Similar conclusions were drawn by Essler and Folk (1961, 1962) from their telemetered heart rate data, obtained in animals (dog, cat, and rabbit) isolated in a soundproof chamber for 48 to $\mathbf{7 2}$ hours.

For restrained rabbits very complete data on the heart rate and other E.C.G. characteristics have recently been published by Häberland and Regoeczi (1963).

The pharmacodynamic action causing changes of electrical heart activity may be very complex. Direct action on the myocardium is probable for volatile anaesthetics and chemically related compounds, as the blood concentrations of these in general anaesthesia are also effective in isolated heart preparations (Pittinger and Keasling, 1959). Interaction with the metabolism of mediators is probable, e.g., for chloral hydrate, which possesses a cholinergic and anticholinesterase activity (Dybing and Dybing, 1955; Krivucová, 1957). Thus depression (or sometimes stimulation) of central nervous control of the heart and the effects of metabolic shifts due to the anaesthetic state cannot easily be distinguished from a direct action on the myocardium in the intact animal. For this reason, E.C.G. recording may often reveal a toxic effect, but gives little indication of the mechanism which causes it.

Heart activity is related to the functioning of the whole animal. Changes in it due to drugs can therefore contribute to an understanding of other toxic effects. For example, the heart depression due to carbon disulphide probably contributes to the fact that no deeper electroencephalographic stages of anaesthesia could be detected for this compound (Horváth and Michalová, 1952, 1956; Mikisková and Mikiska, 1964).

It is more difficult to extrapolate results on guinea-pigs and rabbits to other species and to man than is the case for tests of neurotoxicity. In our previous paper (Mikisková and Mikiska, 1966) we stated that while the E.E.G. patterns after trichloroethylene are strikingly similar in rodents, dog, and man, the incidence of cardiac arrhythmias is largely species-dependent ( $c f$. also Atkinson (1960) and Defalque (I96I)), and likewise for other compounds. Whereas in the experiments by Dési and Nikolits (I967), $6.7 \mathrm{mM}$./kg. of benzene, administered intraperitoneally, did not affect the E.C.G. in cats, in our experiments the same dose decreased the heart rate of guinea-pigs by about 10 to $15 \%$ and caused changes similar to other lipid solvents.

Inter-species differences are encountered also during chronic poisoning. For example, carbon disulphide was reported to alter profoundly the E.C.G. of dogs (Lewey, I94I) but not to affect that of rabbits (Cohen, Scheel, Kopp, Stockell, Keenan, Mountain, and Paulus, 1959; Brieger, De Meio, and Friedman, 1949) in spite of similar signs of central nervous involvement.

Conclusions Electrocardiography is the most convenient technique of monitoring the heart action in laboratory animals. Although the E.C.G. is not directly related to the blood flow, it provides information on the origin and propagation of excitation within the heart.

For screening or pilot experiments, very simple recording techniques and standard equipment are satisfactory. For more detailed examination, suitable electropolygraphs are commercially available. Radio telemetry allows continuous monitoring during exposure to toxic vapours and contributes to an understanding of the course and mechanism of toxic action. 
TABLE VIII

Comparison of the Four Electrophysiological Techniques for Assessing the Toxicity of Industrial Solvents

\begin{tabular}{|c|c|c|c|c|}
\hline $\begin{array}{c}\text { Testing the Action of Narcotic (anaesthetic) Agents } \\
\text { (incl. industrial solvents) }\end{array}$ & $\begin{array}{l}\text { Spinal Reflex } \\
\text { Excitability }\end{array}$ & $\begin{array}{c}\text { Electrical } \\
\text { Excitability } \\
\text { of Motor } \\
\text { Cortex }\end{array}$ & E.E.G. & E.C.G. \\
\hline $\begin{array}{l}\text { Acute toxicity } \\
\text { Proof of presence (screening experiments) } \\
\text { Quantitative (e.g., relative) toxicity data } \\
\text { Time course of intoxication } \\
\text { Analysis of mechanism of action } \\
\text { Comparability with clinical observations } \\
\text { Chronic toxicity }\end{array}$ & $\begin{array}{c}++ \\
++ \\
0 \\
0 \\
0 \\
+\end{array}$ & $\begin{array}{c}0 \\
+ \\
++ \\
++ \\
0 \\
0\end{array}$ & $\begin{array}{l}0 \\
+ \\
+ \\
+ \\
+ \\
\pm\end{array}$ & $\begin{array}{c}+ \\
+ \\
++ \\
\pm \\
\pm \\
++\end{array}$ \\
\hline
\end{tabular}

++ very suitable (method of choice): statistically highly significant results can easily be obtained;

+ suitable;

\pm relevant data may be found for some compounds but cannot be expected in advance;

Onot suitable (for technical difficulties or lack of stability of the studied response).

The normal E.C.G. of guinea-pigs and rabbits is closely similar to that of the human. Experimental results may therefore be compared with clinical observations, although possible inter-species differences in response cannot be ignored.

By allowing for the variation of the heart rate with the animal's age or weight and due to handling interindividual variability can be substantially reduced, and absolute heart rates obtained at various laboratories can be compared.

Table VIII summarizes the strengths and weaknesses of the four electrophysiological techniques for assessing the toxicity of industrial solvents with known or suspected narcotic properties.

\section{REFERENCES}

Andersen, P., and Kaada, B. R. (1953). The electroencephalogram in poisoning by lacquer thinner (butyl acetate and toluene). Acta pharmacol. (Kbh.), 9, 125-130.

Arduini, A., and Arduini, M. G. (1954). Effect of drugs and metabolic alterations on brain stem arousal mechanisms. F. Pharmacol. exp. Ther., 110, 76-85.

Atkinson, R. S. (1960). Trichlorethylene anaesthesia. Anesthesiology, 21, 67-77.

Babskij, A. N., and Malkiman, I. I. (1952). The action of adenosin-triphosphoric acid on the chronaxy of the motor zone of cerebral cortex. (In Russian) Dokl. Akad. Naik SSSR Otd. Biokh., 84, I $135-1138$.

Bartenev, V. D. (196I). Toxicological data on hexafluoropropylene. (In Russian) In Proc. Scientific Conf. Toxicology of Macromolecular Compounds, pp. 21-22. Leningrad.

Bartmann, K., and Reinert, H. (1952). Das Extremitätenund Brustwand-elektrokardiogramm des nichtnarkotisierten Meerschweinchens. Naunyn-Schmiedeberg's Arch. exp. Path. Pharmak., 216, 258-267.

Baryšnikov, I. I., Vinogradov, V. M., Nikiforov, M. I., and Sanin, I. N. (1956). The action of chlorpromazine on some functions of the central nervous system. (In Russian) Zh. vys. sh. nerv. Deyat. Pavlova, 6, 885-890.
Benešová, O., Horváth, M., and Mikiska, A. (1956). Bewertung von Tiefe und Länge der Narkose nach den elektrophysiologischen Eigenschaften der Grosshirnrinde. Physiol. bohemoslov., 5, 188-194.

Bickford, R. G. (1950). Automatic electroencephalographic control of general anesthesia. Electroenceph. clin. Neurophysiol., 2, 93-96.

Bohm, E., and Petersén, I. (1953). Differences in sensitivity to dial of motor effects elicited by stimulation of fore- and hindlimb areas of the cat's motor cortex. Acta physiol. scand., 29, Suppl. 106, I43-149.

Brazier, M. A. B. (1954). The action of anaesthetics on the nervous system (With special reference to the brain stem reticular system). In Brain Mechanisms and Consciousness. Ed. Delafresnaye, J. F., pp. 163-193. Blackwell, Oxford.

Bremer, F., and Bonnet, V. (1948). Action particulière des barbituriques sur la transmission synaptique centrale. Arch. int. Physiol., 56, 100-102.

Brieger, H., DeMeio, R. H., and Friedman, M. H. F. (1949). On the theory and pathology of carbon disulfide poisoning. F. industr. Hyg., 31, 93-105.

Brookhart, J. M., and Zanchetti, A. (1956). The relation between electrocortical waves and responsiveness of the corticospinal system. Electroenceph. clin. Neurophysiol., 8, 427-444.

Burch, G. E., Abildskov, J. A., and Cronvich, J. A. (1953). Spatial Vectorcardiography. Lea and Febiger, Philadelphia.

Bureš, J., Petráň, M., and Zachar, J. (1960). Electrophysiological Methods in Biological Research. Publishing House of the Czechoslovak Academy of Science, Prague.

Burns, B. D. (I95I). Some properties of isolated cerebral cortex in the unanaesthetized cat. F. Physiol. (Lond.), 112, 156-175.

(1954). The production of after-bursts in isolated unanaesthetized cerebral cortex. Ibid., 125, 427-446.

Butler, T. C. (I948). The metabolic fate of chloral hydrate. f. Pharmacol. exp. Ther., 92, 49-58.

Chafetz, M. E., and Cadilhac, J. (1954). A new procedure for a study of barbiturate effect and evoked potentials in the EEG. Electroenceph. clin. Neurophysiol., 6, 565-572. 
Cohen, A. E., Scheel, L. D., Kopp, J. F., Stockell, F. R., Jr., Keenan, R. G., Mountain, J. T., and Paulus, H. J. (1959). Biochemical mechanisms in chronic carbon disulfide poisoning. Amer. industr. Hyg. Ass. F., 20, 303-323.

Courtin, R. F. (1955). Electroencephalographic and clinical observations with trichloroethylene and nitrous oxide anesthesia. Dallas med. F., 41, 613-618.

Defalque, R. J. (196I). Pharmacology and toxicology of trichloroethylene. A critical review of the world literature. Clin. Pharmacol. Ther., 2, 665-688.

Dési, I. (1967). Funktionsstörungen des zentralen Nervensystems bei experimenteller Benzolvergiftung. Int. Arch. Gewerbepath. Gewerbehyg., 23, 58-7I.

- , and Nikolits, I. (1967). Influence of aromatic hydrocarbons on cortical strychnine spikes. Activ. nerv. sup. (Praha), 9, 152-159.

Domino, E. F. (1955). A pharmacological analysis of the functional relationship between the brain stem arousal and diffuse thalamic projection systems. F. Pharmacol. exp. Ther., $115,449-463$.

Drohocki, Z. (1948). L'intégrateur de l'électroproduction cérébrale pour l'électroencéphalographie quantitative. Rev. neurol., 80, 619.

- (1956). An electronic integrator for the automatic measurement of average tension in the EEG. Electroenceph. clin. Neurophysiol., 8, 706-707.

Dybing, F., and Dybing, O. (1955). Anticholinesterase and anticurare effects of chloral hydrate and trichloroethanol. Acta pharmacol. (Kbh.), 11, 398-404.

Essler, W. O., and Folk, G. E., Jr. (I96I). Determination of physiological rhythms of unrestrained animals by radio telemetry. Nature (Lond.), 190, No. 4770, 90-91.

$\longrightarrow$, and - (1962). A method of determining true resting heart rates of unrestrained mammals by radio telemetry. Anim. Behav., 10, 168-170.

Faulconer, A., and Bickford, R. (196I). The Electroencephalogram in Anesthesiology. Thomas, Springfield, Illinois.

French, J. D., Verzeano, M., and Magoun, H. W. (I953). A neural basis of the anesthetic state. Arch. Neurol. Psychiat. (Chic.), 69, 519-529.

Fulton, J. F., and Keller, A. D. (1932). Observations on the response of the same chimpanzee to dial, amytal and nembutal, used as surgical anaesthetics. Surg. Gynec. Obstet., 54, 764-770.

—, Liddell, E. G. T., and Rioch, D. Mc.K. (1930). 'Dial' as a surgical anaesthetic for neurological operations; with observations on the nature of its action. $\mathcal{F}$. Pharmacol. exp. Ther., 40, 423-432.

Furnas, D. W., and Hine, C. H. (1958). Neurotoxicity of some selected hydrocarbons. Arch. industr. Hlth, 18, 9-1 5.

Gangloff, H., and Monnier, M. (1956). Electrographic aspects of an arousal or attention reaction induced in the unanaesthetized rabbit by the presence of a human being. Electroenceph. clin. Neurophysiol., 8, 623-629.

$\longrightarrow$, and - (1957). Topic action of reserpine, serotonin and chlorpromazine on the unanaesthetized rabbit brain. Helv. physiol. pharmacol. Acta, 15, 83-104.

Greville, G. D., and Heppenstall, M. E. (1950). Chapter VI : Pharmacology. In Electroencephalography. A Symposium on its Various Aspects. Ed. Hill, D., and Parr, G. Macdonald, London.

Guedel, A. E. (I95I). Inhalation Anesthesia. 2nd ed., Macmillan, New York.

Häberland, G., and Regoeczi, E. (1963). Ueber die Konstanz der Herzaktion des Kaninchens. Untersuchungen mit Hilfe synchron registrierter Herzstrom- und Herzschallkurven. Z. ges. exp. Med., 137, 123-143.
Hess, R., Jr., Koella, W. P., and Akert, K. (1953). Cortical and subcortical recording in natural and artificially induced sleep in cats. Electroenceph. clin. Neurophysiol., 5, 75-90.

Higashida, T. (1964). Electrophysiological studies on the neurotoxic action of industrial solvents. Proc. 14th int. Congr. Occup. Hlth, Madrid, 1963, 3, pp. I I3I-I 133. Excerpta medica Foundation, Amsterdam. (Int. Congr. Ser. No. 62).

Horváth, M., and Michalová, C. (1952). Changes of EEG in experimental exposure to carbon disulfide in the light of Vvedensky's theory of parabiosis. Abstracts of Communications of Ist Czechoslovak Physiol. Congress, Prague (In Czech) Cs. Fysiol., 1, 262.

- , and (1956). Veränderungen des EEG bei experimenteller Exposition in Schwefelkohlenstoff im Lichte der Lehre Wedensky's von der Parabiose. Arch. Gewerbepath. Gewerbehyg., 15, 131-136.

- , and Mikiska, A. (1957). The effect of carbon disulfide on the central nervous system of the rabbit (an EEG study). (In Czech) Pracov. Lék., 9, 22-28.

Jaroslavskaja, P. I. (1952). The action of benzene on some functions of the central nervous system. (In Russian) In Proc. 2nd Nat. Conf. Probl. Industr. Toxicol., Charkov.

King, E. E. (1956). Differential action of anesthetics and interneuron depressants upon EEG arousal and recruitment responses. F. Pharmacol. exp. Ther., 116, 404-4I 7.

Kolmodin, G. M. (1953). The action of ethyl alcohol on the monosynaptic extensor reflex and the multisynaptic reflex. Acta physiol. scand., 29, Suppl. 106, 530-537.

Korbakova, A. I., Kremneva, S. N., Kulagina, N. K., and Ulanova, I. P. (I960). Impairment of the central nervous system functions in chronic benzene poisoning. (In Russian) In Industrial Toxicology, pp. 232-238. Medgiz, Moscow.

Králová, H., Mikiska, A., and Pařizek, O. (1957). The measurement of the electrical excitability of cortical motor centres: application in industrial toxicology. (In Czech) Pracov. Lék., 9, 44-50.

Krivucová, M. (1957). Inhibition of biological oxidations by trichloroethylene and other compounds. Thesis, Charles Univ., Prague. (In Czech).

Larrabee, M. G., and Posternak, J. M. (1952). Selective action of anesthetics on synapses and axons in mammalian sympathetic ganglia. f. Neurophysiol., 15, 9I-II4.

Lazarev, N. V. (1954). Noxious Compounds in the Industry. Vol. I. (In Russian) Medgiz, Moscow.

Lev, A. A. (1956). EEG changes during increased excitability of the cerebral cortex. (In Russian) Fiziol. Zh. (Mosk.), 42, I02 I-I03I.

Levitina, G. A. (1948). The state of subordination and chronaxy of the cerebral cortex during bulbocapnine catalepsy. (In Russian) In Subordination within the Nervous System in Physiology and Pathology. Ed. Magnickij, A. N. Moscow.

Lewey, F. H. (194I). Experimental chronic carbon disulfide poisoning in dogs. F. industr. Hyg., 23, 415-436.

Ljublina, E. I. (I948). Determining various characteristics of the flexor reflex as a method experimental study of the action $\mathrm{c} f$ industrial poisons on the nervous system. (In Russian) In Scientific Papers of the Institute of Industrial Hygiene and Occupational Diseases. Vol. 12, No. 5, pp. 51-65, Leningrad.

- (1950). (In Russian, quoted from Lazarev, 1954.) Farmakol. i Toksikol., 13, 3, 33. 
Ljublina, (1959). Various methods used in establishing the maximum allowable concentrations. Pracov. Lék., Ir, Suppl. I, 26-28.

Lombard, E. A. (1952). Electrocardiograms of small mammals. Amer. F. Physiol., 171, 189-193.

Longo, V. G. (1962). Electroencephalographic Atlas for Pharmacological Research. Effect of Drugs on the Electrical Activity of the Rabbit Brain. Elsevier, Amsterdam.

Lukoschek, P., and Thiesen, J. (1954). Das normale Meerschweinchen-Ekg. Z. Kreisl.-Forsch., 43, I72-180.

Magoun, H. W., and Rhines, R. (1946). An inhibitory mechanism in the bulbar reticular formation. $\mathcal{F}$. Neurophysiol., 9, 165-171.

Malkiman, I. I. (I954a). On the action of adenosintriphosphoric acid on the excitability of cerebral cortex. (In Russian) Bull. exp. Biol. Med., 37, 14-I7.

- (1954b). The dynamics of variations of cerebral cortex excitability before and after a convulsive paroxysm. (In Russian) Ibid., 38, 27-30.

Mann, H. B., and Whitney, D. R. (1947). On a test of whether one of two random variables is stochastically larger than the other. Ann. math. Statist., 18, 50-60.

Marshall, E. K., Jr., and Owens, A. H., Jr. (1954). Absorption, excretion and metabolic fate of chloral hydrate and trichloroethanol. Bull. Fohns Hopk. Hosp., 95, I-18.

Martin, J. T., Faulconer, A., Jr., and Bickford, R. G. (1959). Electroencephalography in anesthesiology. Anesthesiology, 20, 359-376.

Matoušek, M. (1967). Automatic Analysis in Clinical Electroencephalography. Research Report 9. Psychiatric Research Institute, Prague.

Matthews, B. H. C. (1933). Nerve endings in mammalian muscles. F. Physiol. (Lond.), 78, I-53.

Mikiska, A. (1960). Bestimmung der elektrischen Erregbarkeit der motorischen Grosshirnrinde und ihre Verwendung in der Pharmakologie und Toxikologie. I. Methodik, Kontrollversuche und physiologische Grundlagen. Arch. Gewerbepath. Gerwerbehyg., 18, 286-299.

- (I962). Recording of physiological data on the magnetic tape: application in work physiology and hygiene. Z. Präv.-Med., 7, 283-300.

(1963). Automatic integration of EEG and EMG. (In Czech) Cs. Fysiol., 12, 151-152.

- (I964). Beiträge zur elektrophysiologischen Registrierungstechnik: Integration-Tonbandaufnahme. Proc. int. Symp. Corticovisceral Physiol. Path. Ther., pp. 423-424. Akademie-Verlag, Berlin.

- (1965). Analysis of some electrophysiological methods with respect to their application in industrial toxicology. Thesis, Institute of Industrial Hygiene and Occupational Diseases, Prague. (In Czech).

- (1967). Short-distance radio telemetry of biopotentials in occupational medicine. Z. Präv.-Med., 12, 48-62.

- , and Mikisková, H. (1964). Determining neurotoxicity by some electrographic methods (EEG, EKG, EMG) in guinea-pigs. Activ. nerv. sup. (Praha), 6, 56-59.

Mikisková, H. (1960). Bestimmung der elektrischen Erregbarkeit der motorischen Grosshirnrinde und ihre Verwendung in der Pharmakologie und Toxikologie. II. Wirkung von Benzol, Toluol und Xylol bei Meerschweinchen. Arch. Gewerbepath. Gewer-

behyg., 18, 300-309.
(1962). Beitrag zur Verwendung der Abwehrreaktion auf die elektrische Hautreizung in der Toxikologie der Stoffe mit zentralnervöser Wirkung. I. Bestimmung der Latenz des Beugereflexes bei den Meerschweinchen. Ibid., 19, 51-67.
-, and Mikiska, A. (1960). Bestimmung der elektrischen Erregbarkeit der motorischen Grosshirnrinde und ihre Verwendung in der Pharmakologie und Toxikologie. III. Vergleich der narkotischen Wirkung von Trichloräthylen und Trichloräthanol bei den Meerschweinchen. Ibid., 18, 310-316.

$\longrightarrow$, and - (1962). Beitrag zur Verwendung der Abwehrreaktion auf die elektrische Hautreizung in der Toxikologie der Stoffe mit zentralnervöser Wirkung. II. Bestimmung der Reizschwellenintensität bei den Meerschweinchen. Ibid., 19, 68-75.

- , and - (1963). Evaluation by electrophysiological methods of neurotoxic action of trichloroethylene and some related substances. In 2nd Int. Pharmcol Meeting; Prague; Abstracts Biochemical Pharmacology, Conference Issue, p. 157.

- and - (1964). Elektrophysiologisches Studium der zentralnervösen Wirkung von Schwefelkohlenstoff und anderen Lösungsmitteln. Proc. int. Symp. Corticovisceral Physiol. Path. Ther., pp. 425-427. AkademieVerlag, Berlin.

- , and - (1966). Trichloroethanol in trichloroethylene poisoning. Brit. F. industr. Med., 23, 116-125.

Naess, K. (1950a). An investigation into the excitability of the motor nerve of rabbits under ether anaesthesia. Acta pharmacol. (Kbh.), 6, 8I-9I.

- (I950b). Changes in the excitability curve of the rabbit's motor nerve during ether anaesthesia (with special reference to the mechanism of the stimulating effect of ether). Ibid., 6, 123-126.

- (I950c). Comparison of effect of ether and curare on neuromuscular transmission, investigated by means of prostigmine. Acta physiol. scand., 20, 117-124.

Niemer, W. T., and Magoun, H. W. (1947). Reticulo-spinal tracts influencing motor activity. f. comp. Neurol., 87, 367-379.

Novikov, J. V. (1956). The action of low benzene concentrations in the chronic experiment on higher nervous activity of animals. (In Russian) Gig. $i$ Sanit., 21, No. 2, 20-25.

Okuma, T., Shimazono, Y., and Narabayashi, H. (1957). Cortical and subcortical electrograms in anesthesia and anoxia in man. Electroenceph. clin. Neurophysiol., 9, 609-622.

Oljunin, I. V. (1957). Changes in the activity of nervous system and autonomic functions in animals during adaptation to chronically administered organic solvents. (In Russian) In Proc. 5th Conf. on Problems of Industrial Toxicology, pp. 37-38. Institute of Industrial Hygiene and Occupational Diseases, Leningrad.

- (1958). Adaptation of animals to the narcotics (organic solvents) of two different types of action. (In Russian) pp. 206-210. In Scientific Papers of the Institute of Industrial Hygiene and Occupational Diseases, Leningrad.

Palatnik, S. A. (1949). The summation of subthreshold stimuli in the motor zone of cerebral cortex in poikilothermic animals during catalepsy. (In Russian) Fiziol. Zh. (Mosk.), 35, 27-33.

Pittinger, C. B., and Keasling, H. H. (1959). Theories of narcosis. Anesthesiology, 20, 204-213.

Pratt, C. L. G. (1938). The electrocardiogram of the guineapig. F. Physiol. (Lond.), 92, 268-272.

Rascanu, V., Kapri, M., and Popovici, G. (1939). L'action du chloroforme, de l'évipan et du véronal sur l'activité des centres moteurs corticaux. C.R. Soc. Biol. (Paris), 130, I602-1605. 
Richard, A. (1939). Sur la narcose à l'évipan. Ibid., r30, ror6-1019.

Richtarik, A., Woolsey, T. A., and Valdivia, E. (1965). Method for recording ECGs in unanesthetized guinea-pigs. F. appl. Physiol., 20, ro9r-1093.

Rossi, G. F., and Zirondoli, A. (1955). On the mechanism of the cortical desynchronization elicited by volatile anesthetics. Electroenceph. clin. Neurophysiol., 7, 383-390.

Rozin, M. A. (1954). Determining some time characteristics of hind-limb flexion reflex in animals. (In Russian) In Producing Pathological States in Animals for Studying Experimental Therapy, pp. 183-189. Leningrad.

Sabawala, P. B., and Dillon, J. B. (1958). Action of volatile anesthetics on human muscle preparations. Anesthesiology, 19, 587-594.

Schlag, J. D. A. (I956). Effect of drugs on pyramidal discharges evoked by cortical stimulation. Electroenceph. clin. Neurophysiol., 8, 421-425.

physiological events in cerebral structures during ether anesthesia. Ibid., ro, 305-324.

Schneider, J. (1954). Étude électrographique et électrophysiologique des mécanismes d'action des agents anesthésiques usuels. Rev. neurol., 91, 428-444.

Secher, O. (1950). The peripheral action of ether estimated on isolated nerve-muscle preparation. I. Direct and indirect stimulation. Acta pharmacol. (Kbh.), 6, 371-385.

- (1951a). The peripheral action of ether estimated on isolated nerve-muscle preparation. II. Synergism of ether and curarizing substances. Ibid., 7, 83-93.

- (195 Ib). The peripheral action of ether estimated on isolated nerve-muscle preparation. III. Antagonistic and synergistic actions of ether and neostigmine. Ibid., 7, I03-I 18.

(I95IC). The peripheral action of ether estimated on isolated nerve-muscle preparation. IV. Measurements of action potentials in nerve. Ibid., 7, II9-I3I.
- (195Id). Pilot investigation into the peripheral action of anaesthetics. Ibid., 7, $231-242$.

Serra, C., and Ambrosio, L. (196I). L'elettroencefalogramma in Medicina del Lavoro (Quaderni di Acta neurologica XXI), Naples.

Sherrington, C. (1906). The Integrative Action of the Nervous System. Cambridge.

- (1909). A mammalian spinal preparation. F. Physiol. (Lond.), 38, 375-383.

Shimazono, Y., Okuma, T., Fukuda, T., Hirai, T., and Yamamasu, E. (1953). An electroencephalographic study of barbiturate anesthesia. Electroenceph. clin. Neurophysiol., 5, 525-532.

Speranskij, S. V. (1962). New and modified methods for studying the relative toxicity of metals. In Industrial Toxicology and Clinic of Occupational Diseases of Chemical Etiology, pp. 63-64. Moscow. (In Russian)

Toman, J. E. P. (1952). Neuropharmacology of peripheral nerve. Pharmacol. Rev., 4, 168-218.

-, and Davis, J. P. (1949). The effect of drugs upon the electrical activity of the brain. Ibid., 1, 425-492.

Verdeaux, G., and Marty, R. (1954). Action sur l'électroencéphalogramme de substances pharmacodynamiques d'intérêt clinique. Rev. Neurol., 91, 405-427.

Votava, Z., Benešová, O., and Metyšová, J. (1958). L'action potentiaisatrice de certains derivés de la phenothiazine sur la durée et la profondeur de la narcose au Thiopental. F. Physiol. (Paris), 50, 563-565.

Wilson, F. N., Johnston, F. D., and Kossmann, C. E. (1947). The substitution of a tetrahedron for the Einthoven triangle. Amer. Heart f., 33, 594-603.

Wyke, B. D. (1955). Electrographic monitoring of barbiturate narcosis. Anaesthesia, 10, 247-259.

Zakusov, V. V. (1948). Experimental Data on Pharmacology of Central Nervous System. (In Russian) Medgiz, Leningrad.

- (1953). Pharmacology of the Nervous System. (In Russian) Medgiz, Moscow-Leningrad. 